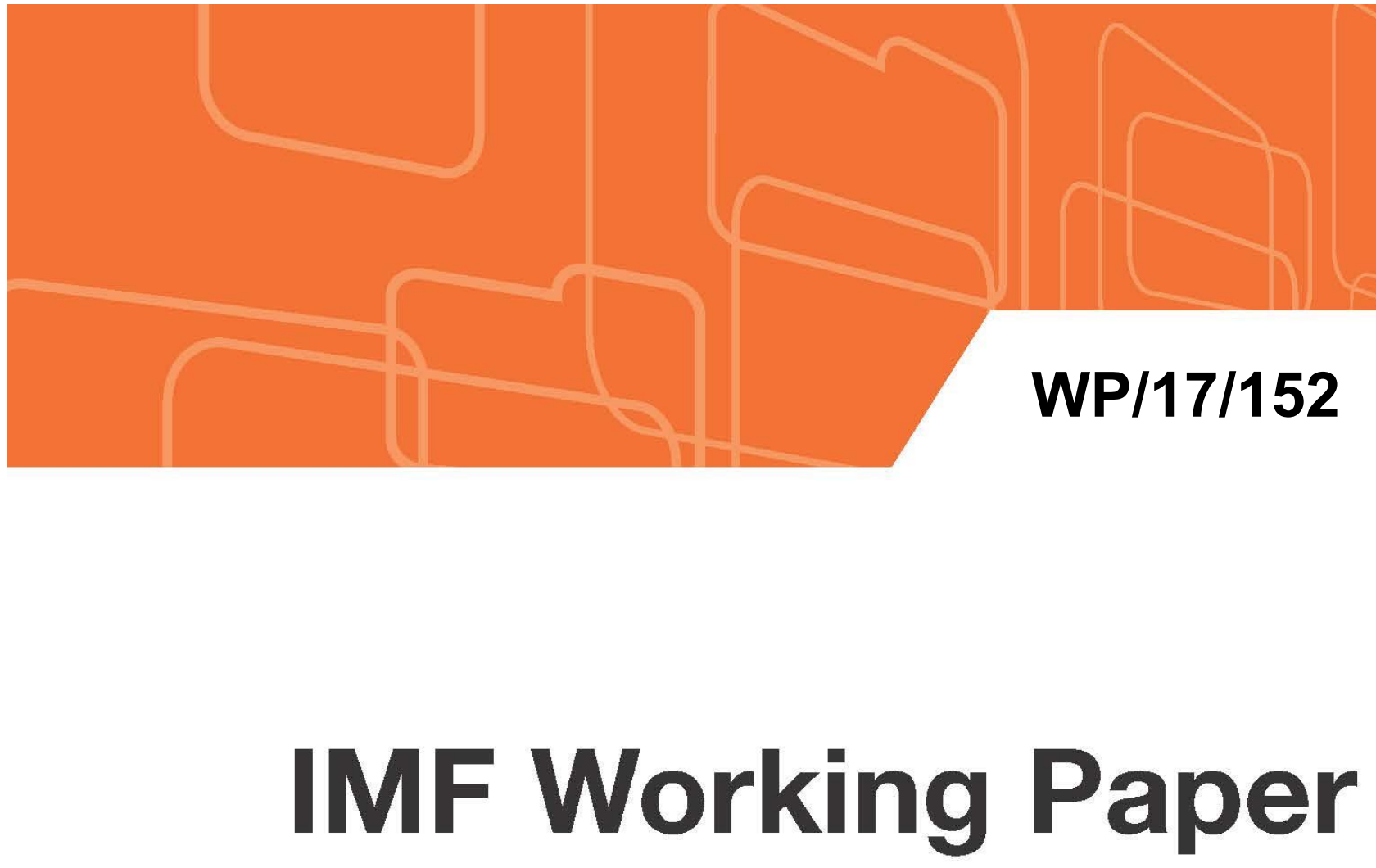

\title{
Central Bank Emergency Support to Securities Markets
}

by Darryl King, Luis Brandao-Marques, Kelly Eckhold, Peter Lindner, and Diarmuid Murphy

IMF Working Papers describe research in progress by the author(s) and are published to elicit comments and to encourage debate. The views expressed in IMF Working Papers are those of the author(s) and do not necessarily represent the views of the IMF, its Executive Board, or IMF management. 


\title{
IMF Working Paper
}

Monetary and Capital Markets Department

\section{Central Bank Emergency Support to Securities Markets \\ Prepared by Darryl King, Luis Brandao-Marques, Kelly Eckhold, Peter Lindner, and Diarmuid Murphy}

Authorized for distribution by Ghiath Shabsigh

July 2017

IMF Working Papers describe research in progress by the author(s) and are published to elicit comments and to encourage debate. The views expressed in IMF Working Papers are those of the author(s) and do not necessarily represent the views of the IMF, its Executive Board, or IMF management.

\begin{abstract}
This paper considers the central bank mandate with respect to financial stability and identifies the links to the functioning of securities markets. It argues that while emergency support to securities markets is an important part of the crisis management response, a high bar should be set for its use. Importantly, it should be used only as part of a comprehensive policy package. The paper considers what types of securities markets may be important for financial stability, what market conditions could trigger emergency support measures, and how programs can be designed to restore market functioning while minimizing moral hazard.
\end{abstract}

JEL Classification Numbers: E58, G21, G23, and G28

Keywords: Lender-of-last resort, liquidity, market maker of last resort, fire sales, and financial stability.

Author's E-Mail Addresses:dking@imf.org; 1marques@imf.org; keckhold@imf.org; plindner@imf.org; and dmurphy@imf.org. 


\section{Contents}

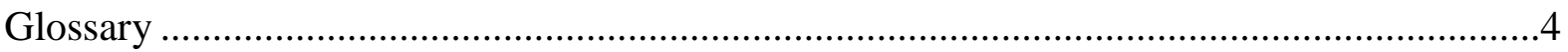

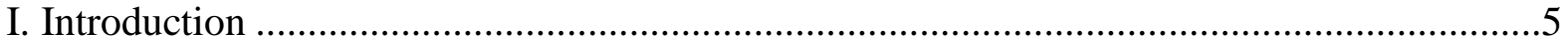

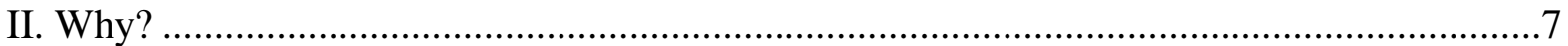

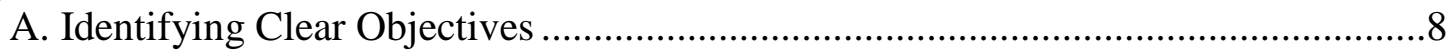

B. Linking the Objectives to Market Functioning .............................................11

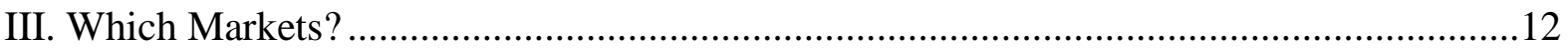

A. Market Liquidity in Normal Times ............................................................12

B. Relative Size and Importance to the Financial System .....................................13

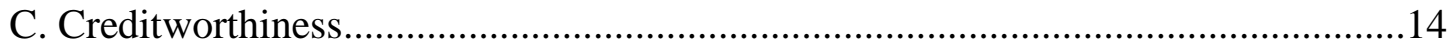

D. Assessing Candidates for Potential Support-An "Intervention Frontier" ............14

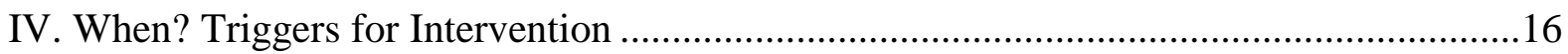

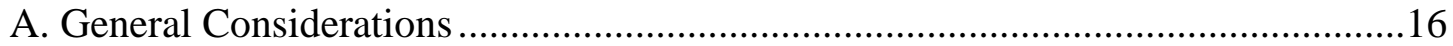

B. Triggers Indicating a Disruption to the Flow of Credit....................................18

C. Triggers Indicating Fire-sale Risks ............................................................19

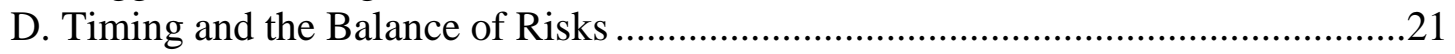

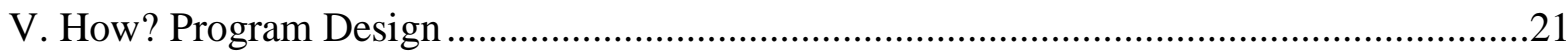

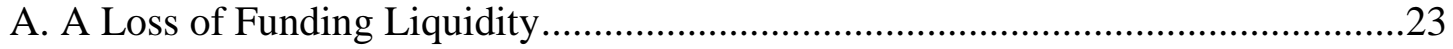

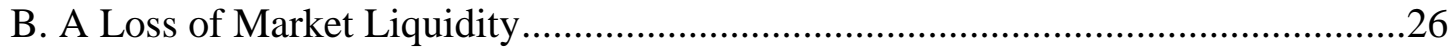

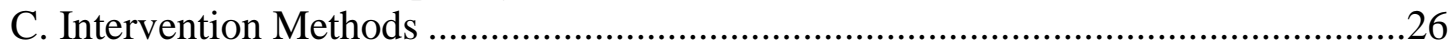

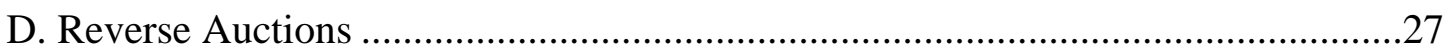

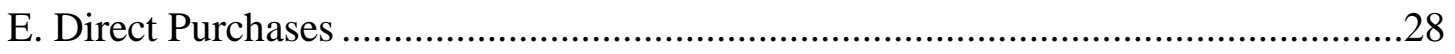

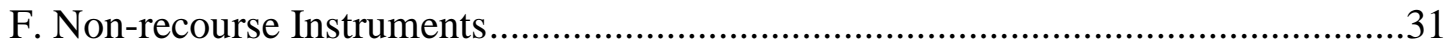

G. Special Purpose Vehicles to Limit Central Bank Risks and Mitigate Moral

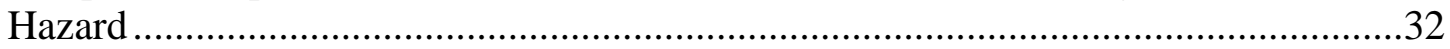

H. Considerations for Effectiveness and for Exit .............................................. 33

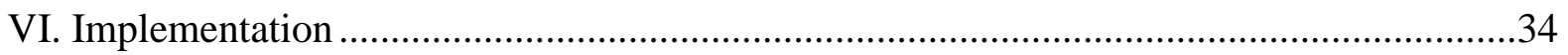

A. Coordination with Other Crisis Management Policies …....................................34

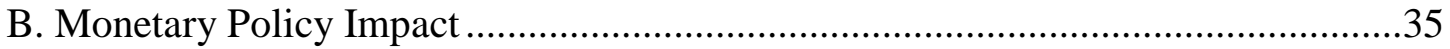

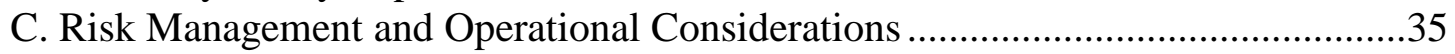

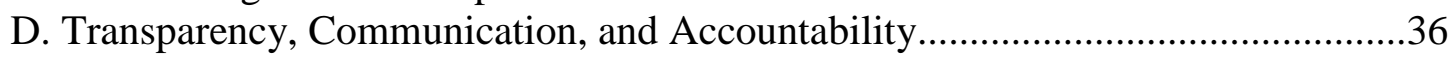

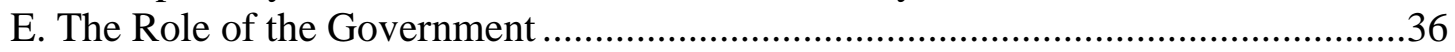

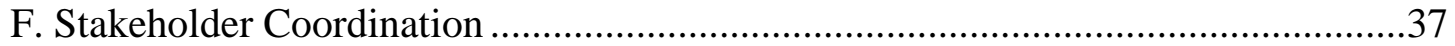

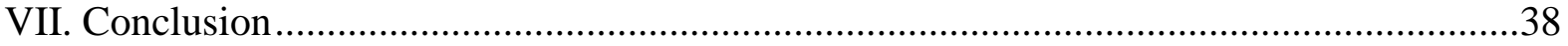

\section{Tables}

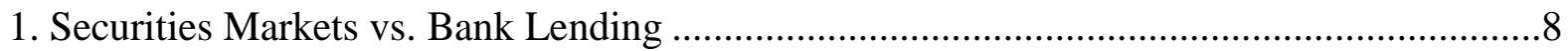

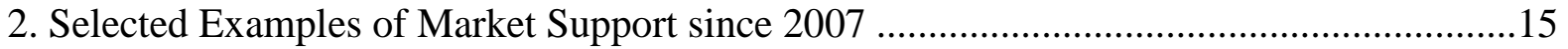

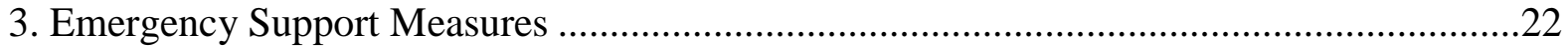

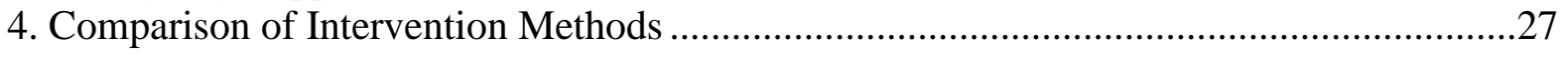




\section{Figures}

1. Emergency Support for Securities Markets_-A Stylized Process .................................... 9

2. Linkages between the Objectives and Market Functioning ...........................................12

3. Intervention Frontier ....................................................................................... 14

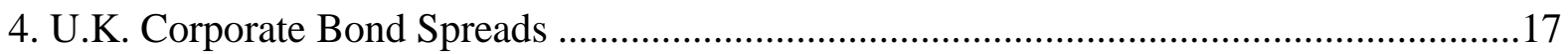

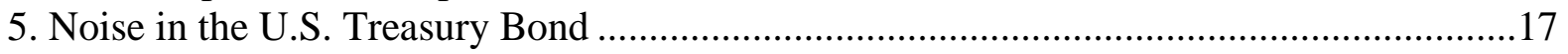

\section{Boxes}

1. Central Bank Actions to Support Market Functioning ....................................................

2. The Bank of England's Commercial Paper Purchasing Program .....................................19

3. The U.S. Federal Reserve Systems's AMLF ............................................................20

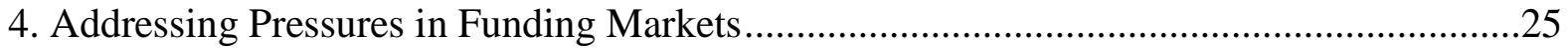

5. Auctions -Fixed Rate: Bank of England Commercial Paper Program..............................29

6. Auctions - Variable Rate: Bank of England's Corporate Bond Program ...........................30

7. The Fed's AMLF to Address Fire Sale Risk ..................................................................32

\section{Appendices}

I. Market Failures — Revisiting the Theory .............................................................. 40

II. Foreign Exchange Intervention Channels ...............................................................41

III. Past Programs to Support Securities Markets .............................................................42

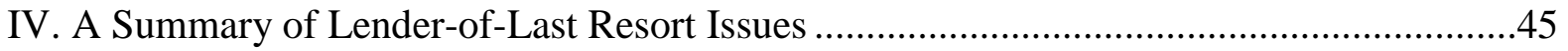

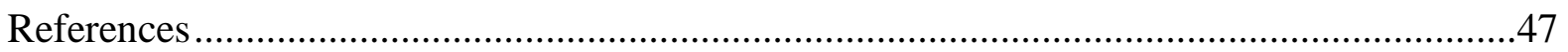




\section{GLOSSARY}

\begin{tabular}{|c|c|}
\hline $\mathrm{ABCP}$ & Asset-backed Commercial Paper \\
\hline $\mathrm{ABS}$ & Asset-backed Securities \\
\hline AMLF & Asset-backed Commercial Paper Money Market Mutual Fund Liquidity Facility \\
\hline $\mathrm{APF}$ & Asset Purchase Facility \\
\hline $\mathrm{BOE}$ & Bank of England \\
\hline BIS & Bank for International Settlements \\
\hline $\mathrm{CCP}$ & Central Clearing Counterparty \\
\hline CGFS & Committee the Global Financial System (BIS) \\
\hline $\mathrm{CP}$ & Commercial Paper \\
\hline $\mathrm{CPFF}$ & Commercial Paper Funding Facility \\
\hline ECB & European Central Bank \\
\hline The Fed & U.S. Federal Reserve System \\
\hline FX & Foreign Exchange \\
\hline GBP & Pound Sterling \\
\hline GFC & Global Financial Crisis \\
\hline HY & High Yield \\
\hline IG & Investment Grade \\
\hline LIBOR & London Interbank Offer Rate \\
\hline LOLR & Lender-of-Last Resort \\
\hline OIS & Overnight Indexed Rate Swap \\
\hline OMO & Open market operation \\
\hline OTC & Over-the-counter \\
\hline MMLR & Market-maker-of-last-resort \\
\hline MMMF & Money Market Mutual Funds \\
\hline MBS & Mortgage-backed Securities \\
\hline NYSE & New York Stock Exchange \\
\hline PD & Primary Dealer \\
\hline PDCF & Primary Dealer Credit Facility \\
\hline PTF & Principal Trading Firm \\
\hline SCP & Secured Commercial Paper \\
\hline SMP & ECB's Securities Market Program \\
\hline SPVs & Special Purpose Vehicles \\
\hline TALF & Term asset-backed Loan Facility \\
\hline TSLF & Term Securities Lending Facility \\
\hline U.K. & United Kingdom \\
\hline U.S./U.S.A. & United States of America \\
\hline US\$ & United States Dollar \\
\hline VaR & Value-at-risk \\
\hline
\end{tabular}




\section{INTRODUCTION}

Market freezes and market liquidity squeezes have occurred in the past with negative consequences. ${ }^{1}$ For instance, in September 2008, liquidity in the U.S. asset-backed commercial paper (ABCP) market evaporated. During this and other exceptional episodes, several central banks around the world provided support to many financial institutions (lending as a last resort) and a few securities markets (making markets as a last resort). During crises, central banks expand the type of operation, lengthen the duration of lending, and broaden the range of counterparties they deal with and the eligible collateral. ${ }^{2}$ In financial sectors where banks dominate, the central bank provision of emergency liquidity may be sufficient to mitigate risks to financial stability when stresses arise. However, as capital markets change and deepen - making banks somewhat less central for financial intermediation - other forms of official support to the financial sector may be needed to maintain financial stability. ${ }^{3}$

The process for supporting illiquid financial intermediaries (mainly banks) has been amply studied and is well-established (Bagehot 1873), even if in practice there are a number of complications in applying the principles of Lender-of-Last Resort (LOLR). However, the discussion of central banks' role in supporting securities markets during periods of market turbulence is more recent and has been more limited (BIS 2014). The goal of this paper is to contribute to the latter discussion.

This paper develops a framework to analyze central bank emergency support to securities markets by answering four broad questions: (1) why should central banks support market functioning?; (2) which markets should be supported?; (3) when should support be given?; and (4) how should central banks support markets? We answer these questions with a conceptual frame of reference that draws from economic theory and central bank practices.

Central banks support markets because doing so will help them meet their mandates with regard to the maintenance of financial stability, and price stability. We identify three intermediate objectives: safeguarding the flow of credit; averting fire sale dynamics; and supporting the transmission of monetary policy. Financial stability can be at risk when securities dealers are unable to sell or refinance inventory, thereby reducing their ability to make markets. Equally, stability risks arise when financial firms (including asset managers) face increasing liquidity demands from their end-investors, or are faced with reduced access to funding by lenders, which might result in fire sales of financial assets; that is, a forced sale

\footnotetext{
${ }^{1}$ Market liquidity is the ability to buy or sell a security without significantly affecting its price. Bid-ask spreads, the size of the order book, and the price impact of trades are examples of measures of market liquidity.

${ }^{2}$ Actions taken to support institutions and markets are distinguished from large-scale asset purchases when the objective was to provide additional monetary accommodation at the zero lower bound.

${ }^{3}$ This paper does not deal with interventions in equities markets because of the absence of a clear relationship between these markets and financial stability. Further, very few central banks have the legal authority to intervene in equity markets.
} 
that results in the asset trading below its intrinsic value. As a consequence, nonfinancial firms and consumers might lose access to finance. Such instances of significant market failure arise as a result of any one or combination of, asymmetric information, incomplete markets, or certain types of externalities. Although ex-ante measures (that is, regulatory settings) - which are not the central theme of this paper - can almost always be tightened (giving rise to the need to assess the costs/benefits of different regulatory settings), there is always a risk of a tail event resulting in a freeze of key markets, and hence the need to consider intervention.

In selecting which markets should be supported, central banks must take into account that their intervention should be truly a last resort action and that the costs of not intervening must always outweigh the potential costs of intervention. Actions that are seen as not being of a last-resort nature give rise to moral hazard - participants may come to believe that their risks are underwritten by the authorities - therefore, potentially amplifying financial stability risks. Official support is best directed at securities markets where liquidity is temporarily impaired but which are normally liquid. In addition, in order to maximize the overall impact on financial stability, while minimizing its balance sheet exposure, central banks should target relatively large and/or connected markets, and those where credit risk is typically low. Thus, benchmark money and bond markets are natural candidates for support.

The appropriate timing of central bank interventions to support markets is, however, complicated by the fact that the underlying market imperfections which drive illiquidity are not easily identifiable. Therefore, central banks need to analyze a wide set of indicators to diagnose the nature of the problem and to determine when to start an intervention. In this context, qualitative information gathered from market participants and quantitative indicators used to time interventions in foreign exchange (FX) markets or measures of pricing noise and of violations of no-arbitrage conditions are likely to be useful.

Given satisfactory answers to the previous three questions- why, which, and when - how should central banks intervene to safeguard or restore temporarily impaired market functioning? In broad terms, central banks can support market functioning through structural measures, the provision of liquidity to financial intermediaries as LOLR, direct intervention as market makers of last resort, or by facilitating markets (Box 1). Yet, we argue that the choice of specific instruments and modalities of intervention depends on whether a loss of funding liquidity or a loss of market liquidity are at the root of the problem. If the lack of funding liquidity is at fault, central banks can use measures - for instance, repos - to sustain collateral valuations or to resolve uncertainty about the creditworthiness of key intermediaries such as securities dealers. However, if the problem is the fragility of market liquidity, central banks can choose tools to remove some price risk (for example, reverse auctions) or reduce information asymmetries (through direct purchases).

We are not the first to discuss the role of central banks as providers of emergency support to securities markets (see Buiter and Sibert 2007). However, the existing literature on this topic often discusses the potential role of central banks as market maker of last resort (MMLR) as an extension of their role as lenders of last resort (BIS 2014), or in the broader context of 
market making and market liquidity (CGFS 2014, 2015). In addition to the conceptual framework and the systematic discussion of central bank actions to support markets - the main contribution of this paper-we add to the literature by placing MMLR in the broader context of official support to securities markets. ${ }^{4}$

\section{Box 1. Central Bank Actions to Support Market Functioning}

Central bank actions to support market functioning can be divided into four categories (see enclosed figure). Structural measures have an impact on market liquidity by changing the volume of securities available through securities lending programs while collateral policies influence liquidity premiums across the securities markets. Liquidity provision, through LOLR-type operations, helps securities dealers when they face funding constraints. Central banks can facilitate markets through establishing alternate trading venues, useful where counterparties are unwilling to transact with each other. And lastly, central bank direct intervention in markets can remove some of the underlying financial risk and help restore price discovery when markets have frozen. Direct intervention is sometimes referred to as market-makerof-last resort but equally, many official actions could also be described as buyer-of-last resort activities.

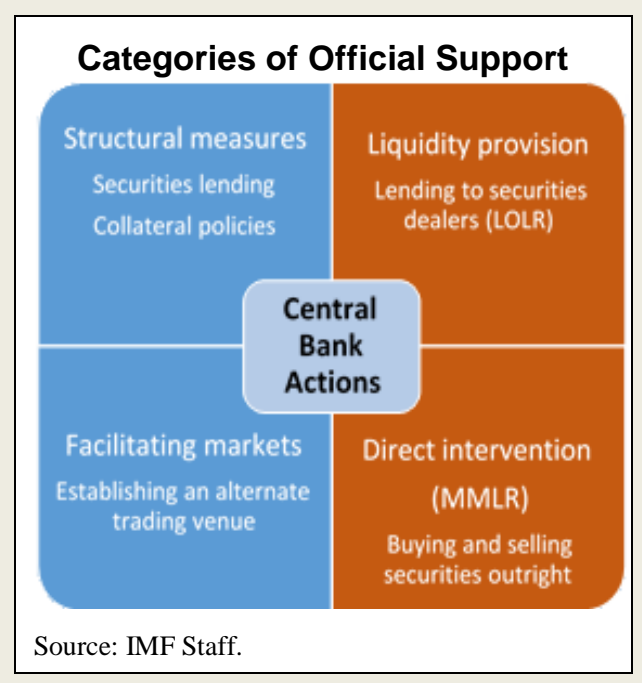

\section{WHY?}

Why should securities markets be supported? At a given level of financial development, a stable financial system facilitates welfare gains that arise from an efficient intertemporal allocation of resources, and provide a greater opportunity for all members of society to store and accumulate wealth. ${ }^{5}$ Securities markets are a key component of the financial system because they allow price discovery and facilitate risk sharing. However, markets sometimes fail (that is, they do not always deliver the best possible outcome) because they may be incomplete, riddled with asymmetric information, or because of externalities (Appendix I.). When such market failures occur, it is possible outcomes could be improved through regulation or other forms of government intervention, including the ones discussed in this paper. ${ }^{6}$

\footnotetext{
${ }^{4}$ In addition to MMLR, these include structural measures such as central bank collateral policies and measures to facilitate markets through alternative trading venues (e.g., conducting two-way auctions).

${ }^{5}$ Schinasi (2006) page 57: “...finance enhances or leverages the public good function of fiat money; it amplifies the universally accepted finality-of-payment services of fiat money, both spatially and intertemporally."

${ }^{6}$ For instance, central bank trades or commitments to trade a security at a certain price can increase market liquidity by reducing the severity of the adverse selection problem caused by asymmetric information since market makers will know that trades initiated by the central bank are not motivated by private information about asset values.
} 
The case for supporting securities markets depends on the relative importance of securities markets for financial intermediation, on their interconnectedness with the rest of the economy, and on the types of intermediaries normally responsible for the provision of market liquidity. In bank-dominated financial sectors (Table 1), the risks to financial stability chiefly derive from risks of deposit runs which can be mitigated through deposit insurance, regulation, and LOLR. In contrast, in financial systems where securities markets are more central to financial intermediation, in addition to regulation and LOLR, there could be a strong case for MMLR and other direct support to markets. In addition, the ongoing trend of principal trading firms (PTFs) ${ }^{7}$ and other nonbanks replacing banks as market makers challenges the resilience of market liquidity (IMF 2015) and the traditional ways in which central banks provide emergency liquidity to financial intermediaries.

\section{Table 1. Securities Markets vs. Bank Lending September 30, 2016}

(In US\$ billions)

\begin{tabular}{lrrrrr}
\hline & $\begin{array}{c}\text { (1) Debt } \\
\text { Securities } \\
\text { Outstanding }\end{array}$ & $\begin{array}{c}\text { (2) Bank } \\
\text { Loans } \\
\text { Outstanding }\end{array}$ & $\begin{array}{c}\text { In Percent } \\
(1) /(2)\end{array}$ & $\begin{array}{c}\text { (3) Central } \\
\text { Gov't } \\
\text { Securities }\end{array}$ & $\begin{array}{r}\text { In Percent } \\
{[(1)-(3)] /(2)}\end{array}$ \\
\hline Euro Area & 16,402 & 13,319 & 123 & 7,689 & 65 \\
Korea & 1,771 & 1,833 & 97 & 543 & 67 \\
Mexico & 710 & 242 & 293 & 375 & 138 \\
United Kingdom & 5,915 & 1,951 & 303 & 2,688 & 165 \\
U.S.A. & 37,614 & 8,566 & 439 & 16,505 & 246 \\
\hline
\end{tabular}

Sources: BIS, Bloomberg, ECB, U.S. Federal Reserve System (The Fed), BOE, Banco de Mexico.

${ }^{1}$ Only credit by private banks is included.

The process when considering emergency support is exceptions-based, in that action is a very rare event and need be considered only when there is a severe disruption to securities markets. Hence, unlike with monetary policy decisions, there is no need for regular communication on why securities markets were or were not supported - which is not to downplay the importance of regular assessments and communication on financial stability issues more broadly. The practical challenges of intervening in securities markets are significant and some useful parallels can be drawn with FX intervention (see Appendix II).

\section{A. Identifying Clear Objectives}

Financial stability objectives are now often enshrined in central bank mandates, yet identifying the appropriate financial stability metrics remains a challenge. A price stability objective requires the setting of a number (or range) of a publicly available price index, with performance against the objective readily observable. In contrast, there is no single metric that adequately encapsulates a notion of financial stability because of its multidimensional nature. The challenge is to identify and define a set of variables that quantifies how well

${ }^{7}$ PTFs are firms that trade chiefly for their own accounts and not on the behalf of others (agency trading). 
financial stability is facilitating processes such as savings and investment, lending and borrowing, liquidity creation and distribution, asset pricing, and, ultimately, wealth accumulation and growth (Schinasi 2006).

\section{Figure 1. Emergency Support for Securities Markets-A Stylized Process}

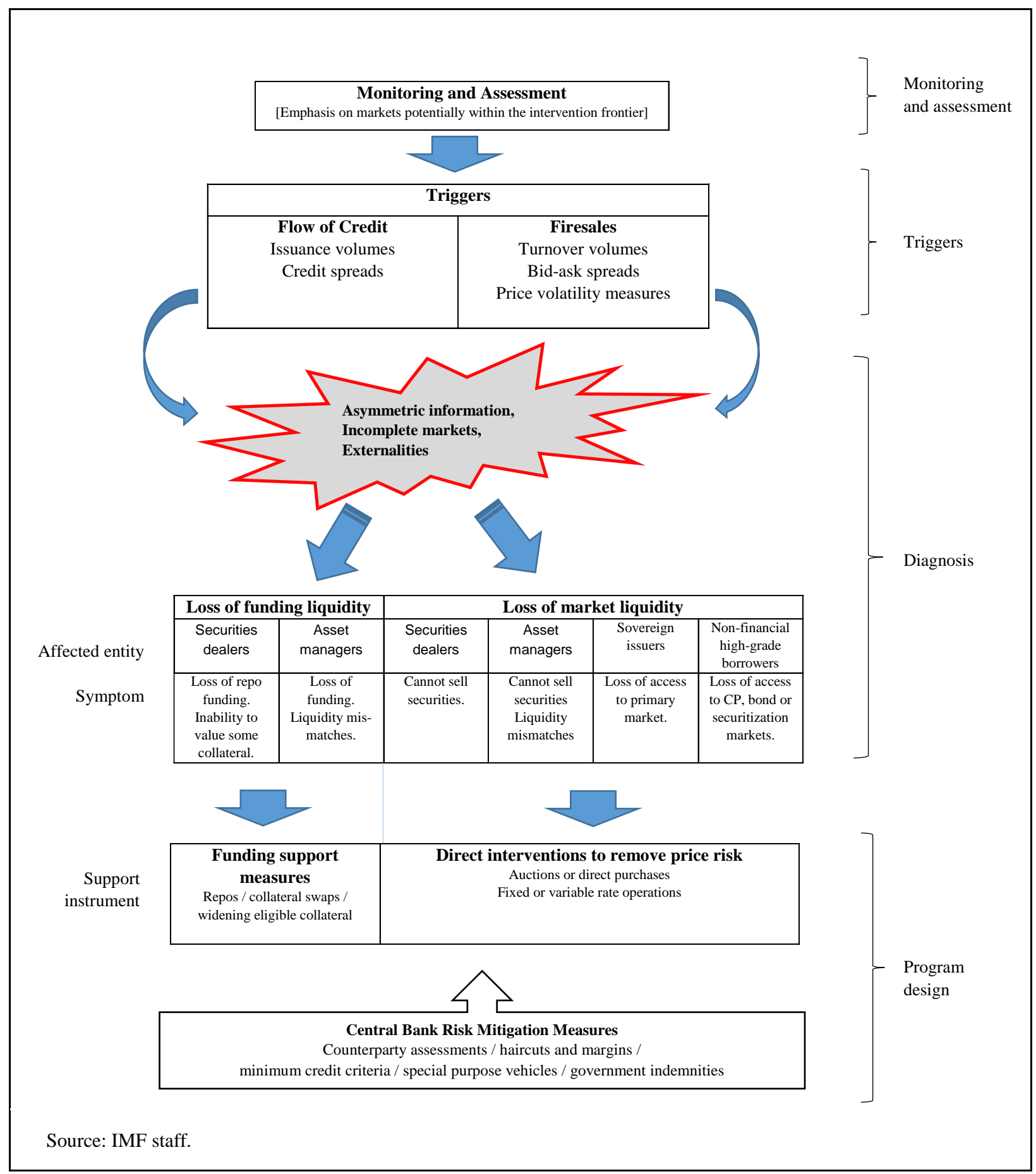


Maintaining financial stability involves a process of monitoring and possibly taking action in the event that financial stability is at risk. ${ }^{8}$ As already mentioned, emergency support for securities markets should be an exceptions-based process - as opposed to the mostly rulesbased approach to monetary policy_-involving a number of components: monitoring and assessing relevant markets, determining the conditions that threaten financial stability (that is, triggers), diagnosing the problem, and designing a program to deal with the problem (Figure 1).

Definitions of financial stability generally incorporate two components that are dependent upon the functioning of securities markets. Clear from the definitions is that financial stability involves continuity in the performance of the core functions of finance - the pricing, management, and allocation of risks and resources - in the context of supporting real economic activity. This continuity could be interrupted, with respect to securities markets, where (1) the flow of credit is severely impeded, and/or (2) asset values diverge abruptly and significantly from fundamental value (that is, fire sales). These two objectives along with a third and related objective, the transmission of monetary policy, are further discussed below.

- Maintaining a satisfactory flow of credit. Individuals rely on credit to finance their purchases, and businesses rely on short-term funding markets for working capital needs while using the long-term securities markets to fund capital expenditures. A freeze in short-term funding markets (for example, for commercial paper (CP)) can have a devastating effect if, for instance, businesses are unable to pay salaries and wages. Investment could be badly affected if longer-term funding markets cease to operate, or if spreads stay too wide for too long.

- Countering fire-sale dynamics. A fall in the value of financial assets below fundamental value can set off a damaging spiral of liquidations and lead to solvency concerns in the financial system. Such a spiral could, in part, result from margin calls made against reduced collateral valuations which may then undermine the ability of intermediaries to fund themselves and make markets in securities. Such fire-sale dynamics may then set up a feedback loop reducing the flow of credit. ${ }^{9}$

- Supporting the transmission of monetary policy. Where there is severe disruption to securities markets resulting in a disruption to the flow of credit, or fire-sale dynamics take hold, the transmission of monetary policy could be undermined. Two central banks (the European Central Bank (ECB) and the Bank of England (BOE)) specifically identify supporting the transmission of monetary policy as a reason why they may intervene in

\footnotetext{
${ }^{8}$ The conduct of monetary policy requires a credible policy framework with clearly defined goals, intermediate targets, operating targets, and instruments. This process is supported by a well-understood theory of how changes in instrument setting impact the ultimate goals; these linkages are commonly referred to as the transmission mechanism.

${ }^{9}$ In addition to reducing collateral values and weakening the balance sheets of financial firms, fire sales can also reduce the flow of credit by encouraging intermediaries to divert resources to trading activities (at fire-sale prices) and away from credit origination (Shleifer and Vishny 2011 and Diamond and Rajan 2011).
} 
securities markets. The objective of the ECB's securities market program (Decision of the ECB of 14 May 2010 - ECB/2010/5) was to "address the malfunctioning of securities markets and restore an appropriate monetary policy transmission mechanism." Further, the BOE's Sterling Monetary Framework (the "Red Book") states that it “...stands ready to act as a market-maker-of-last resort. Any such intervention would aim to improve the liquidity of one or more markets whose illiquidity posed a threat to financial stability or was judged to be important to the transmission of monetary policy."

Supporting the flow of credit and countering fire sales can be viewed as two sides of the same coin, both resulting from a precipitous fall in the demand for securities. The two objectives are not ranked in terms of one or the other being more important, nor are they likely to be mutually exclusive. Where there is evidence that credit flow through a major market (that is, a primary market) had stopped, then demand for such securities will also have fallen in the secondary market, with consequent risk of a fire sale; the causality in this case is from the primary market to the secondary market. Similarly, fire-sale dynamics can emerge at any time in the secondary market - again, an indication that demand for a security has fallen significantly. Here, the primary market will almost certainly be affected too; the causality, in this case, is from the secondary market to the primary market. In responding, it is almost a moot point as to which market is affected first, although the market that is first affected (and its characteristics) could have a bearing on the response (see Section V).

\section{B. Linking the Objectives to Market Functioning}

Linking the identified objectives to the functioning of securities markets is an important step in considering emergency support. Figure 2 illustrates the key markets and segments: the primary and secondary segments of both sovereign and non-sovereign markets and the funding markets that provide a crucial link to all markets. Further, it shows how the functioning of each segment of each market can impact upon the overall objectives. A satisfactory and sustained flow of credit requires well-functioning primary markets, both sovereign and non-sovereign, while activity in secondary markets supports primary issuance through increased transparency in pricing and lower liquidity premiums. It should be noted that maintaining the flow of credit directly to the public sector, is problematic because many operationally independent central banks are forbidden from purchasing public sector securities in primary markets (that is, monetary financing). However, they may be allowed to purchase securities in the secondary market under certain circumstances. Fire sales, by definition, occur in secondary markets, with an imbalance between buyers and sellers leading to misaligned prices. Funding markets affect all markets and particularly the functioning of secondary markets, as they impact the inventory costs of intermediaries and, as such, their ability and willingness to make markets. 
Figure 2. Linkages between the Objectives and Market Functioning

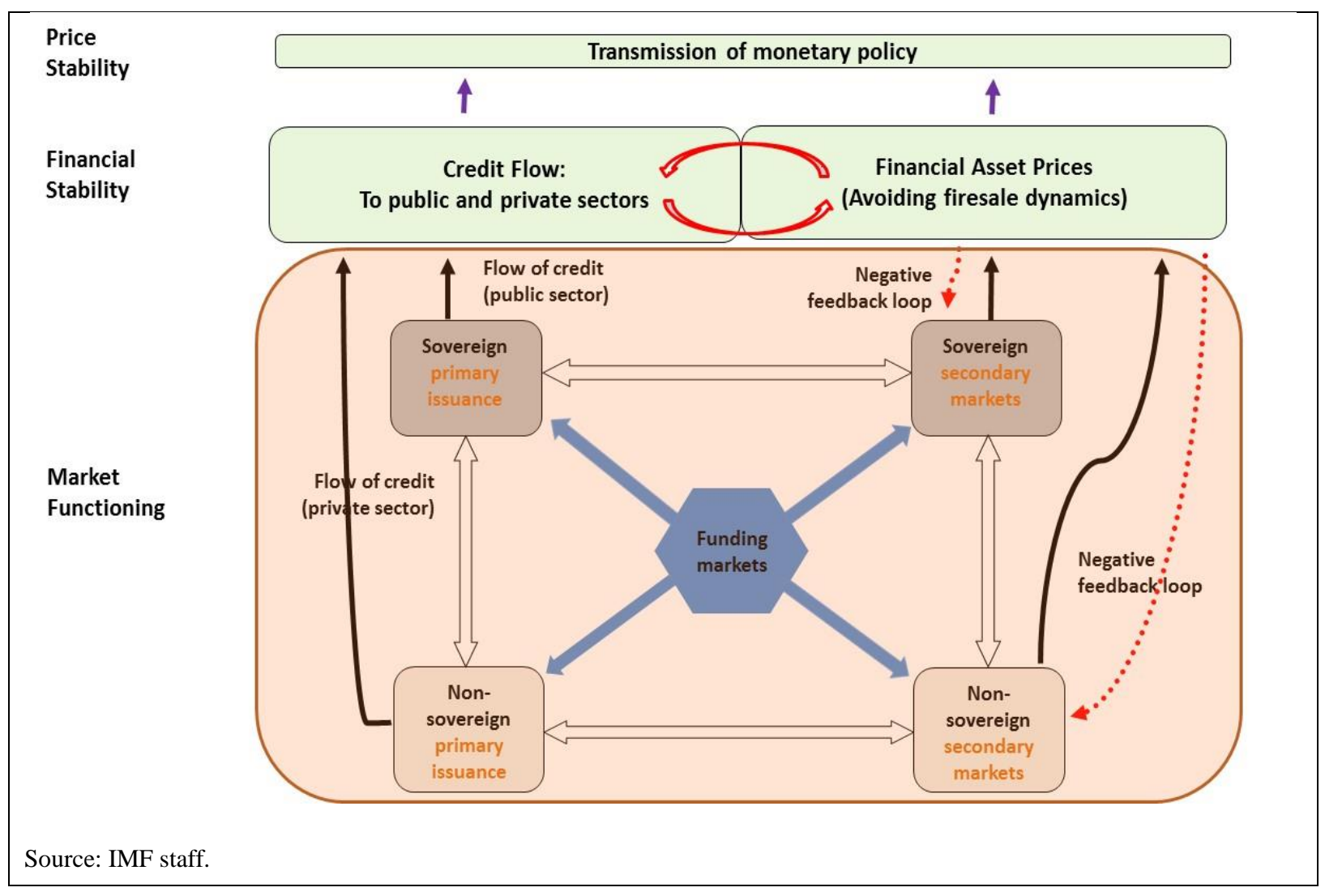

III. WHICH MARKETS?

Official support is best directed at securities markets that are normally liquid, relatively large and/or important, and of a relatively high credit quality. While instability can arise anywhere in the markets, it is neither possible nor desirable to support every market in a crisis. Criteria are required to determine which markets are most worthy of support. As markets and circumstances change, the potential candidates for support may also change, but the criteria for assessing which markets to support should be more robust. The relevant criteria identified are (1) the liquidity of the market for the security in normal times; (2) its relative size and/or importance to the financial system; and (3) the credit quality of the securities in the market in question.

\section{A. Market Liquidity in Normal Times}

Securities that are liquid in normal times are the most likely candidates. Liquidity and trading metrics should be monitored across the spectrum of securities so that deviations from normal patterns can be identified. Such metrics may include outstanding volumes, turnover in primary and secondary markets (including ratios to volumes outstanding) and pricing data (bid-offer spreads and measures of price impact). ${ }^{10}$ The most liquid markets are key to

${ }^{10}$ See IMF (2015) for a survey of relevant market liquidity measures. 
maintaining financial stability and supporting monetary policy transmission, as economic agents use them frequently to manage and price risks. Hence, the more liquid a market is during normal times, the greater the threat to stability and transmission if that market freezes. Also, the most liquid markets are those most able to be resuscitated, as they are habitually used by participants who will be keen to return once normality resumes. In principle, there exists a liquidity continuum, from the most liquid benchmark government securities to illiquid securities such as high yield corporate bonds (Marx and Connolly 2015).

\section{B. Relative Size and Importance to the Financial System}

Larger and more important markets are more worthy of support. The largest markets are generally more important and will have a greater impact on financial stability if functioning breaks down. However, importance is a function of more than just market size, as failures in some smaller markets could amplify a shock through the financial system. ${ }^{11}$ The interconnectedness of the particular market is a key consideration in determining importance. For example, freezes in small, highly interconnected markets (for example, where collateral is widely used in repo transactions) could have a severe adverse impact on financial stability, as could disruptions in markets where information is critical to price other assets (for example, forward markets). Another important aspect could be the ownership of the securities, as a fire sale in an asset that is widely held, or perhaps concentrated in an important segment of the financial system, could lead to solvency concerns in key parts of the financial sector. The relative importance of a particular market (commercial paper markets, for example) will vary across countries.

Countries with better developed financial markets should focus on markets that are important to the flow of credit. In bank-centric financial systems the key markets will be those in which banks raise financing while in others, the wider capital markets, such as commercial paper and corporate bond markets, will also be important, as might be securitized markets. Key financing markets (repo and interbank money markets) will generally be important for liquidity in other securities markets. In some circumstances, intervention in derivatives markets could be justified on account of their importance.

Benchmark money and bond markets are natural candidates for support. Benchmark government bond and Treasury bill markets tend to be the largest, to be those where exposures are the highest, and to be the most widely held, since they are safe assets and high quality collateral and thus play a key role in price discovery. Changes in the functioning of these markets have direct knock-on effects to the functioning of other credit channels and can be associated with dislocations between monetary policy benchmark rates and the cost of credit to the wider economy.

\footnotetext{
${ }^{11}$ For example, if securities dealers lose access to funding, their diminished ability to warehouse risk and make markets could result in widespread disruption across the financial sector.
} 


\section{Creditworthiness}

Securities of a higher credit quality will generally be better candidates for support. The authorities will need to limit the extent of the financial risks associated with market support operations by establishing minimum credit standards for any instrument they are prepared to support. Hence, even if a market is deemed important, it may not be supported because it is too risky. Additionally, markets of a higher credit quality tend to have a wider appeal to endinvestors, are generally larger, and are more likely to satisfy the criteria for being a benchmark market, and thus are more likely to be viable over the long term.

\section{Assessing Candidates for Potential Support-An "Intervention Frontier"}

Assessing the candidates for possible support is necessarily a subjective process. No precise set of trade-offs will be relevant in all situations, and there is no equation that quantitatively links the concepts of liquidity, importance, and credit quality to the notion of financial stability. Rather, significant judgment is

Figure 3. Intervention Frontier required that combines quantitative data in terms of its importance to meeting the objectives (for example, the flow of credit) with qualitative information on how markets are functioning, and how the failure of a particular market might feed through to other markets.

Conceptually, the three identified criteria can be tied together into an Official support is more justified in markets that are more important, normally more liquid, and with lower credit risk.

intervention frontier. In three-dimensional normalized space (Figure 3) each criterion occupies an axis. The limits along each axis (that is, for a given criterion) up to the frontier represent securities that could potentially be supported in the event of market stress. Within the frontier, therefore, is the set of possible supportable securities, while those beyond the frontier are not eligible for support because (1) they are not sufficiently large, important, or interconnected; (2) they are not normally liquid enough; or (3) they entail too much credit risk. The intervention frontier is a concept which in practice cannot be thought of as a hard boundary because of the uncertainties involved. Instead, some key markets could be identified as justifying support (such as sovereign bonds) while others would clearly be identified as not to be supported (such as sub-investment-grade niche securities). The basic 
idea of the frontier is to illustrate that the further the distance from the origin, the weaker the case for support.

It is useful to consider the security types that were supported during the last crisis against the identified criteria. Securities from six jurisdictions (Table 2) are placed within this framework: The euro area, the United Kingdom (U.K.), the U.S.A., Korea, Indonesia, and Mexico. In most cases, the securities were very liquid during normal times and were a relatively large and important part of the financial sector. The euro area covered bonds that had previously been liquid while being a relatively small part of the predominantly bankbased financial sector. The minimum credit rating for all private sector securities was set high, in recognition of the risks to central bank balance sheets and ultimately to taxpayers. The credit rating of government bonds was less of an issue given that they are usually the least-risky domestic currency asset in an economy, although complexities arise in the case of currency unions as experienced in the euro area.

Table 2. Selected Examples of Market Support since $2007^{12}$

\begin{tabular}{|c|c|c|c|}
\hline Security Type & $\begin{array}{c}\text { Liquidity in Normal } \\
\text { Times }\end{array}$ & $\begin{array}{l}\text { Relative Size and } \\
\text { Importance }\end{array}$ & $\begin{array}{c}\text { Minimum Credit } \\
\text { Rating }\end{array}$ \\
\hline \multicolumn{4}{|l|}{ Euro Area } \\
\hline $\begin{array}{l}\text { Government bonds (SMP) } \\
\text { (Greece, Ireland, Italy, } \\
\text { Portugal, Spain) }\end{array}$ & Very liquid & Very important & BBB-/Baa3 ${ }^{13}$ \\
\hline Covered bonds (CBPP1) $)^{14}$ & Liquid & Important & BBB-/Baa3 $^{15}$ \\
\hline \multicolumn{4}{|l|}{ U.K. } \\
\hline Commercial paper & Very Liquid & Very Important & $\mathrm{A} 1 / \mathrm{P} 1$ \\
\hline Corporate bonds & Liquid & Very Important & A- \\
\hline \multicolumn{4}{|l|}{ U.S. } \\
\hline Commercial paper & Very Liquid & Very Important & $\mathrm{A} 1 / \mathrm{P} 1 / \mathrm{F} 1$ \\
\hline Asset-back securities & Very Liquid & Very Important & AAA \\
\hline \multicolumn{4}{|l|}{ Korea } \\
\hline Commercial paper & Liquid & Important & No \\
\hline Corporate bonds & Very Liquid & Very Important & No \\
\hline \multicolumn{4}{|l|}{ Indonesia } \\
\hline Government bonds & Very Liquid & Very Important & No \\
\hline \multicolumn{4}{|l|}{ Mexico } \\
\hline Government bonds & Very Liquid & Very Important & No \\
\hline $\begin{array}{l}\text { IPAB bonds } \\
\text { (Deposit Insurance Agency) }\end{array}$ & Liquid & Very Important & No \\
\hline
\end{tabular}

Source: IMF staff.

\footnotetext{
${ }^{12}$ Not all securities within a given category that meet the minimum criteria are accepted. There could for example be requirements of minimum issuance or tranche sizes.

${ }^{13}$ Or if the rating was below this threshold, eligibility could be granted/maintained based on compliance with an EU-IMF financial assistance program.

${ }^{14}$ The objective of CBPP1 was to provide emergency support to the flow of credit while subsequent covered bond purchase programs (CBPP2 and CBPP3), were aimed at easing monetary and financial conditions with money market interest rates at the effective lower bound.

${ }^{15}$ Covered bonds were required to have at least one rating no lower than AA, while none of its ratings could be below the stipulated BBB-/Baa3.
} 


\section{WHEN? TRIGGERS FOR INTERVENTION}

\section{A. General Considerations}

While a broad range financial market indicators need to be monitored, the markets most relevant to financial and price stability are of particular interest. The focus naturally will be on markets most critical to maintain a satisfactory flow of credit to the economy, and where financial sector exposures and liquidity mismatches are such that a sudden change in asset prices might promote fire-sale activity.

Both primary and secondary markets are of interest. While the concept of market liquidity usually focuses on secondary markets, sometimes important channels for credit do not have actively traded secondary markets (for example, short-term commercial paper markets). Trends in primary issuance volumes and the coverage levels of auctions will often be an important early sign of problems, while the secondary markets will struggle to operate effectively if primary markets are impaired. Also, primary markets could be negatively impacted if secondary markets become unduly volatile or freeze.

The indicators suggesting potential intervention stem from the underlying market failures in each case. The drivers of market failure identified earlier-asymmetric information problems, network externalities as liquidity declines, and the presence of incomplete markets given funding constraints - all cause dealers to withdraw from markets and will be reflected in the indicators that need to be watched for potential need for intervention.

The cause of a market failure may not be easily identifiable in the midst of a crisis and may well result from a mix of problems. In general, the drivers of market failure will not be orthogonal. For example, a significant decline in market activity can be associated with asymmetric information problems among participants (some traders are more informed than others) and financing constraints as repo market liquidity dries up. This implies that a range of indicators need to be analyzed to diagnose the nature of the problem and to determine whether and how the authorities can best intervene to support securities markets.

The types of indicators used for FX intervention are likely to be useful in the context of securities markets. Such metrics would include trading and pricing data such as bid-offer spreads and measures of price impact (IMF 2015). Acceleration in the pace of interest rate changes, seemingly unwarranted increases in interest rate volatility, a widening in bid-offer spreads, and sudden changes in the level or composition of turnover in secondary markets for securities might all be monitored for signs of illiquidity that might precede market breakdown. ${ }^{16}$ In the case of credit spreads, implied default probabilities can provide an

\footnotetext{
${ }^{16}$ See Canales-Kriljenko, Guimaraes, and Karacadag (2003) for a discussion in the context of the conduct of FX intervention.
} 
indicator of whether the observed level of spreads is associated with economic activity considered normal by the central bank or indicative of fire-sale dynamics. ${ }^{17}$

Indicators that suggest that players have withdrawn from the market leaving an imbalance with resultant low liquidity are important. Asymmetric information issues associated with high uncertainty among market participants about the fair value of a security will tend to be strongly reflected in volatility of security prices and spreads and wider than usual bid-offer spreads. An example in the global financial crisis (GFC) was the sudden widening in U.K. corporate bond spreads to risk-free rates (Figure 4) that the BOE took as an indicator of dysfunction in the market. Other measures of the degree of dispersion of security prices (see Figure 5) around the benchmark curve (Hu, Pan, and Wang 2013) and measures that capture violations of no-arbitrage conditions (Pasquariello 2014, index of financial market dislocations) could give another suitable gauge of emerging liquidity problems.

Figure 4. U.K. Corporate Bond Spreads

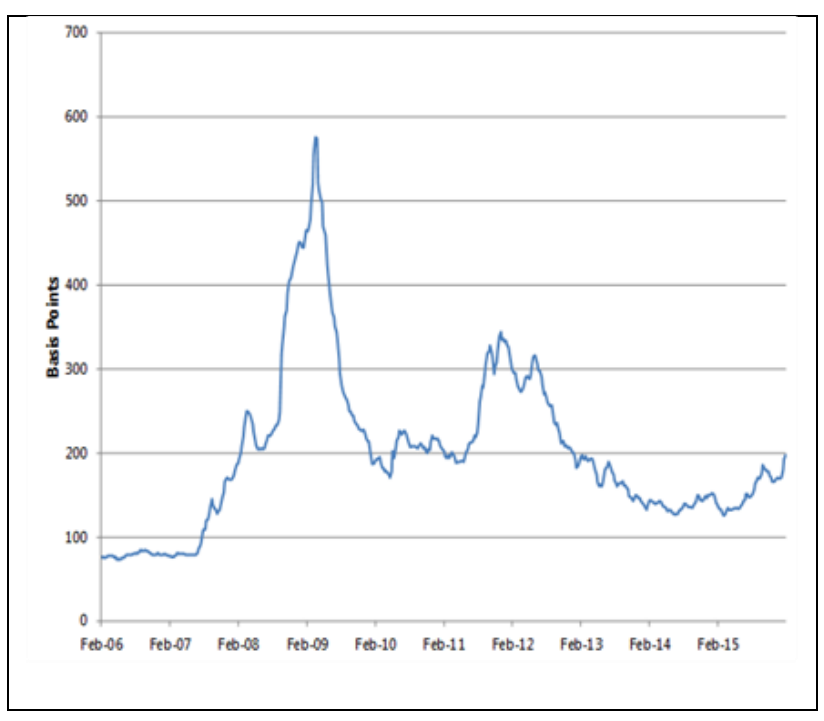

Source: Bloomberg Plc.

\section{Figure 5. Noise in the U.S. Treasury Bond}

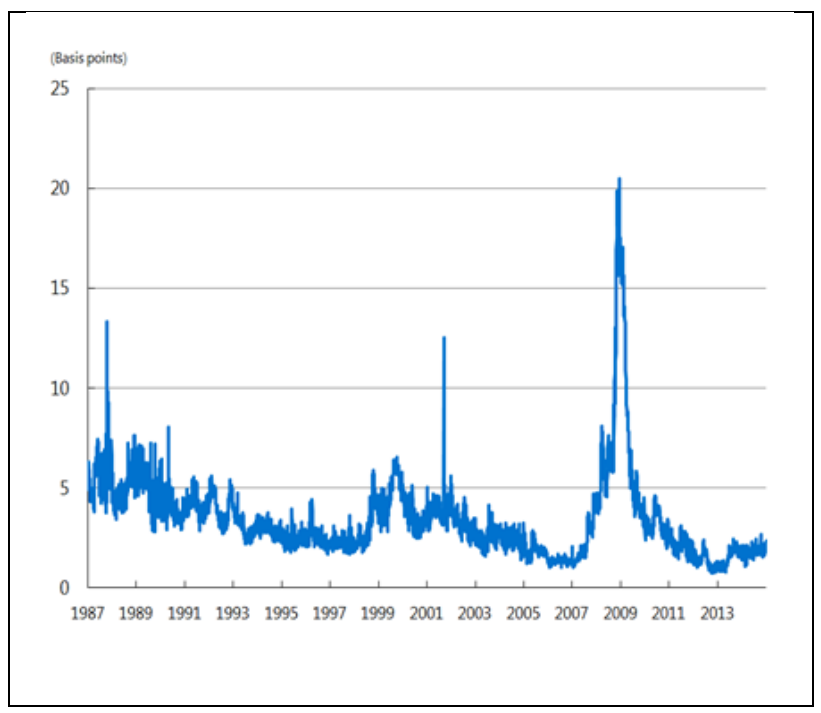

Sources: Hu, Pan, and Wang (2013).

An unusually fast and large decline in market activity is a strong sign of problems. To a significant extent, liquidity begets liquidity in markets reflecting their network characteristics. The depth and resilience of both primary and secondary markets will be eroded as traded volumes decline. An example is the U.K. commercial paper markets during the GFC where primary issuance volumes declined quickly in the wake of the Lehman Brothers failure in late 2008, prompting the BOE to commence regular auction purchases of

\footnotetext{
${ }^{17}$ For example, in the global financial crisis a useful indicator of the need for intervention in the bond markets was the sharp widening in the option-adjusted spreads of investment-grade and high yield corporate bonds over equivalent maturity treasury bonds. These spreads reached levels that far exceeded those consistent with historical default rates observed during the Great Depression of 1932/35.
} 
commercial paper to support the flow of credit to U.K. corporates. Note that there is evidence that liquidity freezes are sometimes preceded by trading frenzies (Easley, Lopez-de-Prado, and O'Hara 2012), and/or price run-ups (Bond and Leitner 2015). Hence, some indicators of aggregate market activity could be leading indicators in some circumstances. ${ }^{18}$

A failure in underlying financing and repo markets will lead to dealer funding constraints and a reduction in market liquidity. The number of participants in, and traded volumes of, repo/financing markets will naturally be an important indicator/driver of market dysfunction in securities markets. These issues were especially important factors motivating the Fed's actions to support commercial paper and asset-backed markets during the GFC period.

Changes in the indicators will likely be more important than their actual level, as structural changes in markets may be occurring. It is difficult to estimate the equilibrium level of indicators such as credit spreads, bid-offer spreads, and trading volumes, as these all can undergo structural changes over time. The shock that motivates intervention can also be a trigger for structural change, which can often make it inappropriate to target a particular level of liquidity or spread. An example in the GFC was the BOE's experience with the CP market, which never regained its pre-GFC trading volumes after the BOE commenced operations. However, the auctions helped the market find a new, lower equilibrium level of activity, and intervention was scaled back once this level had been found.

Qualitative information gained from discussions with market participants may be at least as important as quantitative indicators. The data are helpful for building a case for intervention but much of it may only be available at a lag (for example, market depth in over-the-counter markets). Interconnectedness in particular could be difficult to show quantitatively ex-ante as normal correlations between markets often do not apply in crisis situations. The authorities should maintain a close running dialog with market participants to add this key qualitative element to the analytical process, while being mindful of the risk that some participants may attempt to skew information for their own advantage.

\section{B. Triggers Indicating a Disruption to the Flow of Credit}

Indicators of the functioning of the primary markets where a significant amount of funding for the real economy is raised will have a more prominent focus. In bank-centric economies the focus will be on the markets that banks use to raise funds (covered bonds, bank bill, repo markets). In more diverse financial sectors, the focus will be also on segments where nonfinancial corporates raise finance ( $\mathrm{CP}$, corporate bond markets).

The trigger for intervention will be a judgment that it is no longer feasible for firms to raise funds at reasonable prices to meet working capital or investment needs. The volumes raised in the primary markets and their tenor will be important considerations supplemented with

\footnotetext{
${ }^{18}$ For instance, the accumulation of large order flow imbalances - that is, when the volumes of buyer-initiated and seller-initiated trades become very different — can signal that an important underlying market friction-in this case, asymmetric information—is becoming a serious threat to market liquidity.
} 
any intelligence suggesting that firms' economic activities are being impacted due to financing considerations. A good illustration of the trigger for intervention to support the flow of credit is provided by the timing of the BOE's CP Program (Box 2). Here, sharp widening in credit spreads and a fall in issuance were the triggers for emergency support.

\section{Box 2. The Bank of England's Commercial Paper Purchasing Program}

The BOE commenced a program for purchasing commercial paper in February 2009 after market conditions deteriorated to the point where it had become difficult for U.K. corporates to raise funding (see Figure).

The key indicators were a sharp widening of the spreads on commercial paper and an associated decline in primary market activity (secondary market turnover was generally low in normal circumstances).

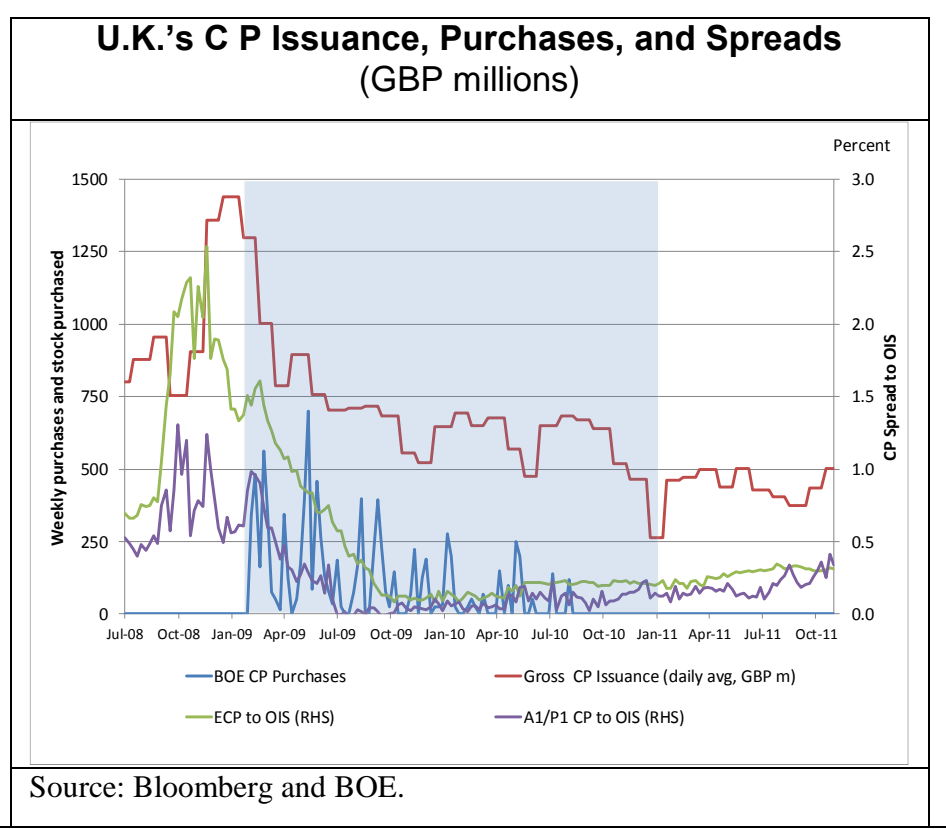

\section{Triggers Indicating Fire-sale Risks}

Indicators of failing secondary market activity and uncertainty regarding asset valuations are more important in situations where fire sales are more likely. Typically, fire sales describe events when market prices fall quickly and substantially below presumed fundamental values in the midst of heavy trading. Important drivers of fire sales are (1) forced sales by asset managers resulting from investors redeeming their shares; (2) a reduction in inventory carried by dealers combined with less unwillingness to make markets; (3) the loss of financing by dealers or levered investors; or (4) when the uncertainty about asset values has increased to the point that many investors are unwilling to continue holding them.

A failure in underlying financing and repo markets will lead to dealer funding constraints and a decline in market liquidity. The number of participants, the traded volumes, and the types of collateral accepted in the repo and financing markets will naturally be an important indicator/driver of market dysfunction in securities markets. These issues were especially important factors motivating the Fed's actions to support commercial paper and asset-backed markets during the GFC.

Most measures of fire sales rely either on investor flows or on deviations of prices from fundamentals. Although difficult to measure, fire sales have been the subject of many research papers which have proposed metrics that can be useful in certain contexts. For instance, Coval and Stafford (2007) proposed three measures of price pressure caused by 
mutual fund flows which can also be generalized to interbank markets. ${ }^{19}$ Measures based on hedonic prices - that is, residuals of econometric regressions of prices on fundamentalsmay be useful as well (see Pulvino 1998).

\section{Box 3. The U.S. Federal Reserve System's AMLF}

In the wake of the failure of the Primary Reserve Money Market Fund on September 19, 2008, a run on prime money market mutual funds (MMMF) started, leading to fire sales in the ABCP market. Investors withdrew US $\$ 300$ billion from prime MMMFs during one week in September 15, 14 percent of the sector's assets. Institutional funds, which constituted 63 percent of all prime MMMF assets, withdrew 10 percent of their assets in one day during that week. In the last two weeks of September 2008, MMMFs reduced their CP holdings by US $\$ 200$ billion. ABCP spreads widened, while the $\mathrm{ABCP}$ market contracted by close to US $\$ 30$ billion during the week of September 16 (see Figure). Further sales of $\mathrm{ABCP}$ would have meant additional reductions in their prices, potentially leading more prime MMMFs to break the buck.

To break the cycle of forced sales by MMMFs of ABCP the Fed launched the AMLF on September 19, 2008. The sudden increase in spreads, coupled with the fast pace of redemptions of MMMF shares, and the decrease in $\mathrm{ABCP}$ liquidity were the main factors behind this decision.

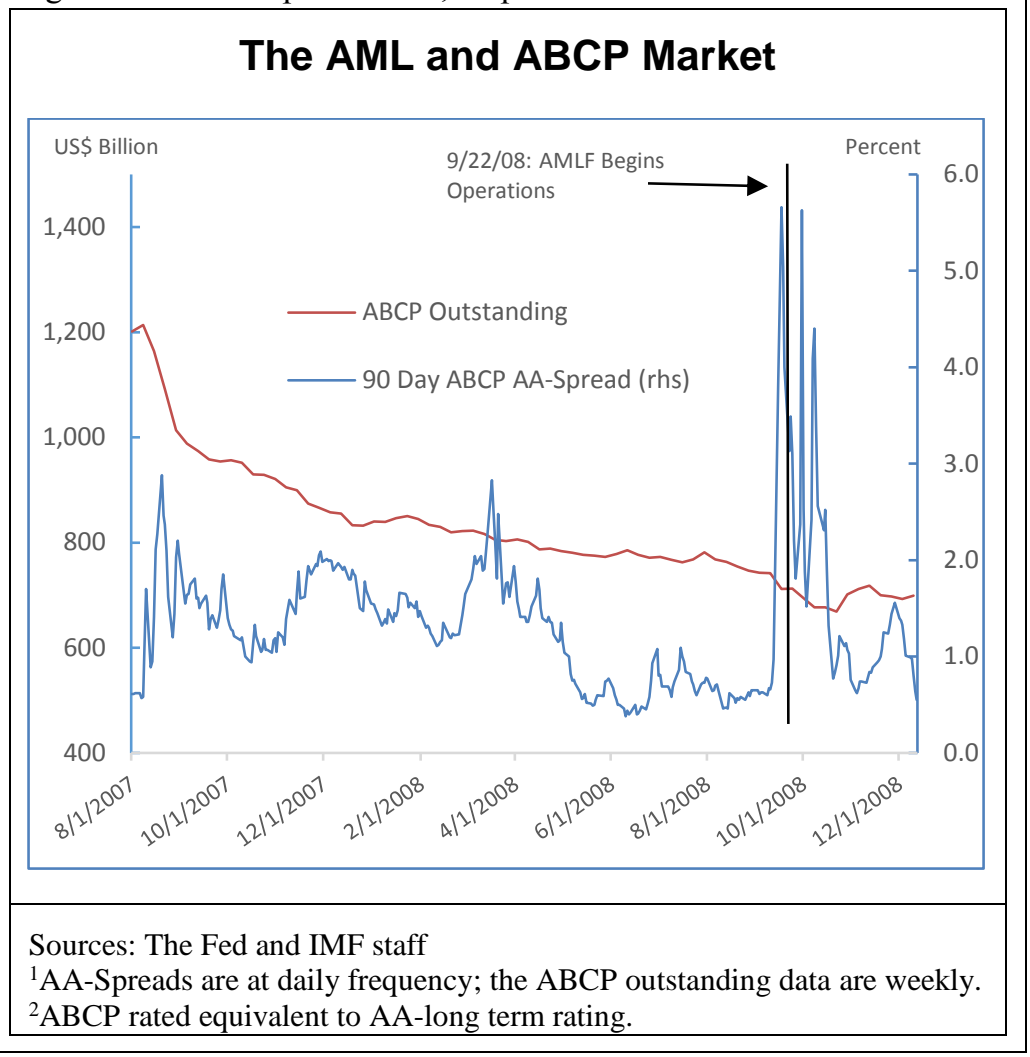

Traditional FX intervention market liquidity analogues are especially useful in this context. Measures of the depth of the market (the volume of the order book on both sides of the market), its resiliency (the amount which can be traded without a significant change in the price) and tightness (the width of bid offer spreads relative to normal conditions) will all provide indications of fire sale risks. Increased volatility of interest rates and credit spreads are similarly important indicators. An illustration of the trigger for intervention to counter fire-sale dynamics is provided by the Fed's Asset-backed Commercial Paper Money Market Mutual Fund Liquidity Facility (AMLF) (Box 3). Here, sharp moves in credit spreads accompanied by heavy mutual fund redemptions triggered a response.

\footnotetext{
${ }^{19}$ The Coval and Stafford metrics compare the changes the holdings of each security by funds that have experienced the largest (10th percentile) and smallest (90th percentile) outflows. The assumption, in this case, is that fire sales are being caused by redemption pressures originating from the funds' investor base. Jotikasthira, Lundblad, and Ramadorai (2012) propose a similar measure based on fund flows with significant price effects. Both metrics can be adapted to the interbank market by using deposit outflows instead of fund outflows. In both cases - interbank market and mutual fund activity - the Coval and Stafford metrics signal the emergence of a market failure driven by an underlying financial friction (in this case, fire-sale externalities which cause runs).
} 


\section{Timing and the Balance of Risks}

The timing of emergency support in securities markets is critical. In the GFC, many markets experienced problems over a relatively short period. Some major commercial banks, securities firms, insurance companies, and other nonbank financial institutions as well as short- and longer-term funding markets all experienced serious problems - there was no doubt that intervention across many markets was needed, and needed fast. But will that be the case next time, or could it be that slower-moving events across markets gradually take on a systemic dimension? At what point, does it become systemic and threaten the identified objectives?

Where events move somewhat slower and may not encompass the entire financial system, determining the trigger point for intervention will be more difficult. There are risks to acting too late as well as too soon. A response that is delayed for too long may cause avoidable harm to markets, institutions, and the economy more broadly, while acting too soon may give the markets comfort that others are backstopping their risk-taking, thereby creating moral hazard. A rigorous focus on assessing how the key indicators are impacting the identified objectives - the flow of credit, fire sales, and the transmission of monetary policy-should help here. However, in the midst of a crisis, either fast or slow moving, the authorities must ultimately make a judgment call; this cannot be a rule-based decision.

\section{How? Program Design}

After concluding that the threats to financial stability are sufficiently serious to warrant a response, the task, then, is to diagnose the source of the problem and design an effective program. Here, a particular challenge is to provide incentives for the restoration of marketbased activity in the impaired segments, while minimizing moral hazard - achieved in part by not publicly pre-committing to any particular course of action. It is stressed that intervention in securities markets is a last-resort measure.

A focus on last-resort actions must not, however, distract from efforts to improve market resiliency through appropriate incentives for proper risk management and self-insurance in markets (see Table 3 for ex-ante measures). While progress has been made since the GFC to improve the resiliency of markets and financial institutions, risks and challenges remain: potential liquidity mismatches in the asset management industry and the growth of highfrequency trading, to name two. Regulation and market structures may need to change further to adequately mitigate these and other evolving risks in securities markets.

Accurate diagnosis of the underlying problems and tailoring a response is critical in effectively dealing with the problem. A range of symptoms can be identified (Table 3), each potentially impacting different market participants in distinctive ways. While the triggers identified in the previous section are important in determining that some action is warranted, establishing the source of the problem requires investigation into the activities of the participants - in other words, securities markets do not exist in isolation. The identified symptoms impact a range of market participants - intermediaries, asset managers, sovereign 
issuers, and nonfinancial borrowers - and can usefully be grouped into two categories: the loss of funding liquidity, and the loss of market liquidity. Clearly there is a close link between these two dimensions of liquidity, because when securities dealers lose the ability to fund asset inventories, market liquidity will deteriorate. And if liquidity in a particular asset is diminished, then individual dealers (or the segment as a whole) who are assumed to be exposed to that asset, may suffer reduced ability to obtain funding by posting collateral.

\section{Table 3. Emergency Support Measures}

\begin{tabular}{|c|c|c|c|c|}
\hline Problem & Indicators / Catalysts & $\begin{array}{c}\text { Ex-ante Measures } \\
\text { (Preventative) }\end{array}$ & Security Type & $\begin{array}{c}\text { Possible Emergency } \\
\text { Support }\end{array}$ \\
\hline \multirow{4}{*}{$\begin{array}{l}\text { Loss of } \\
\text { Funding } \\
\text { Liquidity }\end{array}$} & \multirow{3}{*}{$\begin{array}{l}\text { Securities dealers } \\
\text { cannot fund assets } \\
\text { because: } \\
\text { 1. Uncertainty about } \\
\text { counterparty } \\
\text { creditworthiness } \\
\text { 2. Uncertainty about } \\
\text { collateral values }\end{array}$} & \multirow{3}{*}{$\begin{array}{l}\text { Regulation: capital, } \\
\text { liquidity, leverage. }\end{array}$} & Sovereign bonds & $\begin{array}{l}\text { Liquidity provision } \\
\text { (Repo) }\end{array}$ \\
\hline & & & $\begin{array}{c}\text { Corporate bonds, } \\
\text { ABS }\end{array}$ & $\begin{array}{l}\text { Liquidity provision } \\
\text { (Repo/asset swap) }\end{array}$ \\
\hline & & & $\mathrm{CP}$ & Direct intervention \\
\hline & $\begin{array}{l}\text { Asset managers } \\
\text { Redemption } \\
\text { pressures (liquidity } \\
\text { mismatches) }\end{array}$ & $\begin{array}{l}\text { Regulation: } \\
\text { Adequate liquidity } \\
\text { tools (buffers, swing, } \\
\text { pricing, gates, fees) }\end{array}$ & $\begin{array}{c}\text { Sovereign bonds, } \\
\text { Corporate bonds, } \\
\text { ABS, } \\
\text { CP }\end{array}$ & $\begin{array}{l}\text { Liquidity provision } \\
\text { (Repo) }\end{array}$ \\
\hline \multirow{6}{*}{$\begin{array}{l}\text { Loss of } \\
\text { Market } \\
\text { Liquidity }\end{array}$} & $\begin{array}{l}\text { Asset managers } \\
\text { Redemption } \\
\text { pressures (liquidity } \\
\text { mismatches) }\end{array}$ & $\begin{array}{l}\text { Regulation: } \\
\text { Adequate liquidity } \\
\text { tools (buffers, swing } \\
\text { pricing, gates, fees) }\end{array}$ & $\begin{array}{c}\text { Sovereign bonds, } \\
\text { Corporate bonds, } \\
\text { ABS, } \\
\text { CP }\end{array}$ & Direct intervention \\
\hline & $\begin{array}{l}\text { Securities dealers } \\
\text { cannot sell assets at } \\
\text { reasonable prices }\end{array}$ & $\begin{array}{l}\text { Supportive market } \\
\text { microstructure. } \\
\text { Structural measures }\end{array}$ & $\begin{array}{c}\text { Sovereign bonds, } \\
\text { Corporate bonds, } \\
\text { ABS, } \\
\text { CP }\end{array}$ & Direct intervention \\
\hline & $\begin{array}{l}\text { Sovereign issuers } \\
\text { cannot issue } \\
\text { securities at } \\
\text { reasonable prices }\end{array}$ & $\begin{array}{l}\begin{array}{l}\text { Coherent debt } \\
\text { strategy }\end{array} \\
\text { Supportive market } \\
\text { microstructure. }\end{array}$ & Sovereign bonds & Direct intervention \\
\hline & \multirow{3}{*}{$\begin{array}{l}\text { Non-financial high- } \\
\text { credit-worthy } \\
\text { borrowers lose } \\
\text { access to } \\
\text { commercial paper, } \\
\text { corporate bond, or } \\
\text { securitization } \\
\text { markets. }\end{array}$} & \multirow{3}{*}{$\begin{array}{l}\text { Encourage } \\
\text { diversified funding } \\
\text { arrangements } \\
\text { (difficult to regulate } \\
\text { nonfinancial sector) }\end{array}$} & $\mathrm{CP}, \mathrm{ABCP}$ & Direct intervention \\
\hline & & & Corporate bonds & Direct intervention \\
\hline & & & ABS & Direct intervention \\
\hline
\end{tabular}




\section{A. A Loss of Funding Liquidity}

A loss of funding liquidity may be the easier of the two dimensions to identify and address. Securities dealers are crucial to the functioning of securities markets and their reliance on wholesale funding markets makes funding difficulties easy to spot. First, repo rates would increase (relative to risk-free rates), possibly in conjunction with an increase in collateral margins demanded by lenders, and, finally, selling pressure could emerge in otherwise sound securities with potential for fire sales where funding pressures are acute. Problems here could arise through two channels: uncertainty about the underlying collateral values (possibly itself related to market liquidity) and/or an increase in counterparty credit risk.

Central banks can undertake collateral swaps to address valuation problems in lesser rated collateral. When funding for riskier collateral (for example, corporate bonds or ABS) has become very expensive or impossible to obtain while repo markets for higher quality securities remain active, then the central bank can swap the risky collateral for safe collateral - say, corporate bonds for government securities - enabling the participant to regain access to funding markets by repurchasing the government securities. This approach supports market activity and can be implemented provided that there are few or no uncertainties about the soundness of the participants involved and the adequacy of collateral. However, there are risks to the central bank given the nature of the collateral it receives. These risks should be mitigated through haircuts and with perhaps compensation in form of fees charged. An illustration of a collateral swap program is the Fed's Term Securities Lending Facility (TSLF) (Box 4).

Central banks can substitute for a loss of funding liquidity by directly offering repos where there is uncertainty about the creditworthiness of the securities dealer. Repo markets are largely intermediated by banks or nonbank securities dealers. If these markets break down, then uncertainty about the creditworthiness of the intermediaries could be the cause. To address this problem, central banks could offer a relatively straightforward program that would be an expansion of standard open market operations. The maturity of funding could be lengthened and the range of collateral extended to encompass securities where problems are observed. Other points to be considered here are the following:

- The securities eligible under such a program would be those identified in the previous section (Section III, Which Markets?) and possibly those that are part of the central bank's normal collateral framework. It may be that some securities to which dealers are heavily exposed and which are seen as important for maintaining financial stability are not part of the collateral framework. In this case, the collateral framework could be expanded to include such assets.

- The central bank should ensure that additional risks are well managed. In the case of repo, standardized documentation would mitigate the legal risks while market and credit risks should be assessed and mitigated through appropriate haircuts, which conceivably would be higher than in normal times. 
- The central bank would need to choose between targeting either a repo volume or the repo rates (or spreads). Critical to the success of the operation is to ensure that sufficient funding is provided to alleviate the funding pressures.

- The central bank could estimate what it considers to be the funding need, and offer a fixed volume through a variable rate auction. In this way, the repo price would reveal the extent of the funding pressure, but there is a risk that the demand for funding could be underestimated. To mitigate the uncertainty about the market's funding need, the central bank could conduct several auctions over a short period, adjusting the volumes in response to market pricing.

- Alternatively, repo funding could be offered at a fixed rate (that is, as a margin over a risk-free rate) with full allotment. The challenge then is to identify a rate that is higher than in normal times which participants can reasonably afford, and that provides incentive for the market to resume functioning. Using a fixed rate with full allotment method (limited only by the amount of eligible collateral that the intermediaries are prepared to repo) may be more appropriate when there are extreme funding pressures that need to be addressed. An example of this approach was the Fed's Primary Dealer Credit Facility (PDCF) that provided dealers with discount window-type access against an expanded pool of collateral (Box 4).

- If the dealers are not regular counterparts of the central bank or are not supervised by it, or if there is market segmentation hampering the transmission of monetary policy through the set of market participants, the central bank may need to expand its counterparty list. However, in doing so it should ensure that it is dealing with entities that are compliant with all relevant financial regulations and are financially sound. This may be challenging if the central bank is not the supervisor, highlighting the need for coordination among different stakeholders if emergency support is provided.

Central banks could also consider transactions with asset managers where funding arrangements have been pulled, although the risks of exacerbating the first-mover advantage may be very high. ${ }^{20}$ Asset managers in some cases have funding arrangements (for example, repo or bank credit lines) to augment cash buffers in the event of a surge in redemptions. ${ }^{21}$ If repo markets become inaccessible or bank lines are withdrawn during periods of stress, then they may be forced into selling securities sooner and in greater volumes than would have been the case had the funding arrangements remained in place; fire sales could result. The central bank would need to carefully consider the impact of lending to asset managers as

\footnotetext{
${ }^{20}$ First mover advantage concerns open-end mutual funds and the incentives arising from the distribution of investment losses and trading costs between those that redeem their shares early, and those that stay invested.

${ }^{21}$ Vanguard, the world's second largest fund manager which oversees US\$3 trillion of assets, announced on September 23, 2016 that it was increasing its credit lines to more than US\$3 billion in order to meet emergency redemption requests during times of stress.
} 
such lending (whether by the central bank or any other entity) involves leverage and could exacerbate first-mover advantages and amplify liquidity pressures. ${ }^{22}$

\section{Box 4. Addressing Pressures in Funding Markets}

Primary dealers (PDs) are the counterparts to the Fed's operations and access funding through the triparty repo market. They are critical to the efficient distribution of liquidity and securities throughout the U.S. financial system. The triparty repo market came under severe pressure in 2008 and as a result, market functioning deteriorated significantly. Two Fed programs helped ease funding pressures - as evidenced by a reduction in the OIS-LIBOR (London interbank offered rate) spread (see Figure) - and support a return to more normal market conditions.

\section{Term Securities Lending Facility of the Federal Reserve System}

In March 2008, the Fed established the Term Securities Lending Facility (TSLF) allowing primary dealers to borrow U.S. Treasuries for a period of 28 days against less liquid collateral-agency securities, agency mortgage-backed securities, and AAA/Aaa-rated private label residential mortgage-backed securities. By acquiring Treasuries, the PDs could then enter the repo market to source funding, thereby supporting marketbased activity. This program was conducted through uniform-price auctions and was closed in February 2010. There was also a program offering options on TSLF over periods of heightened collateral pressure (typically month end).

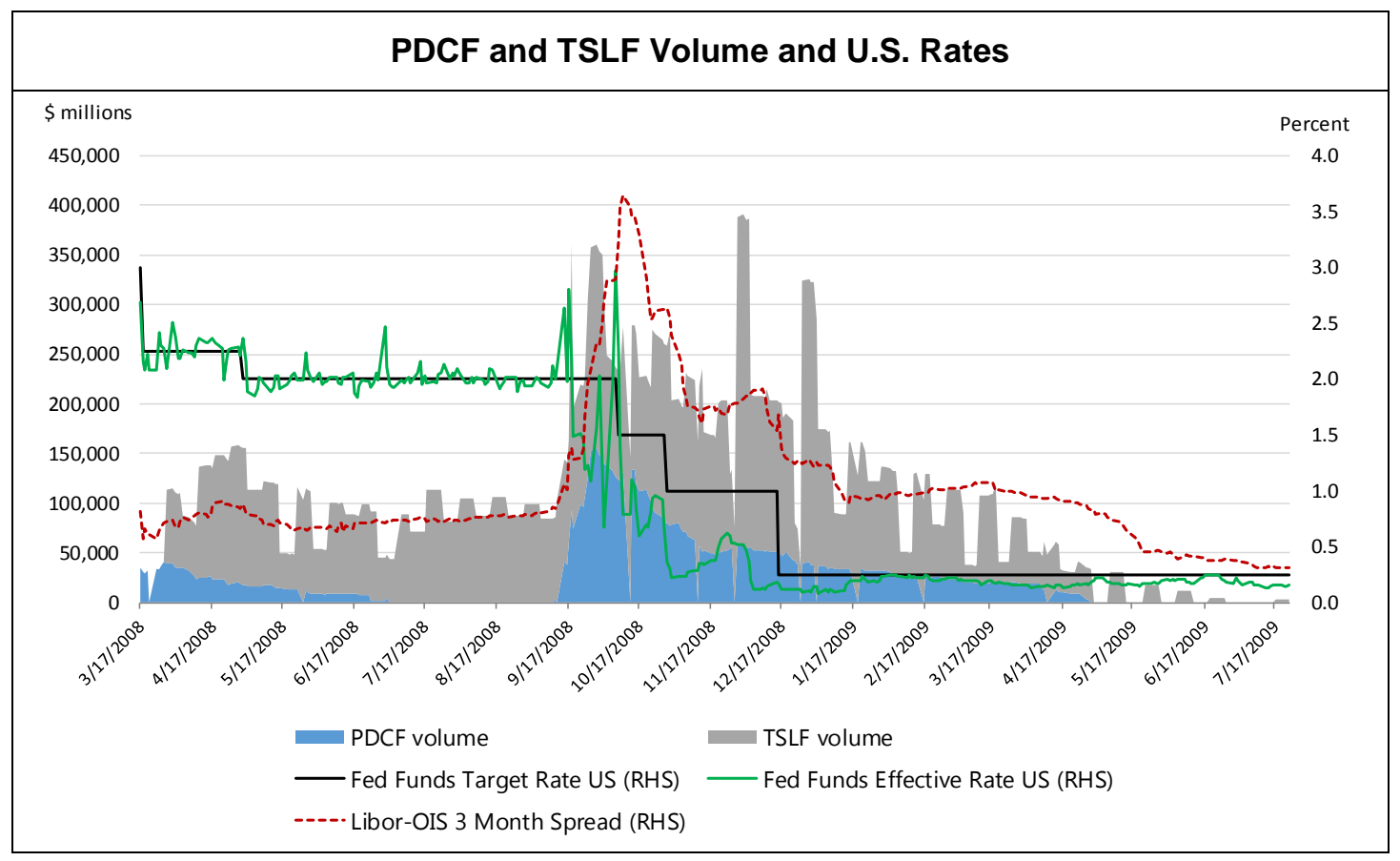

Source: Bloomberg, the Fed, and IMF Staff.

\section{Primary Dealer Credit Facility (The Federal Reserve System)}

The Primary Dealer Credit Facility (PDCF) was also established in March 2008 allowing PDs access to overnight funding collateralized with investment-grade securities and at the same rate applied to Primary Credit Facility (i.e., discount window borrowings by depository institutions). In September 2008, the range of eligible collateral was expanded to include all collateral that could be pledged in the triparty repo system. At the outset, it was announced that the facility would be available for at least six months. After extensions, it operated until May 2009, for a total of 14 months.

${ }^{22}$ Leverage of funds may also be constrained by regulations-like the Investment Company Act of 1940 in the U.S. - or conditions laid out in a fund's prospectus. 


\section{B. A Loss of Market Liquidity}

A loss of market liquidity in important parts of the market can have widespread implications across a range of financial market participants. Common to such episodes is that markets become one-sided, perhaps with extreme selling pressures leading to fire sales, and sometimes with a complete market freeze where no prices can be observed. As a result:

- Asset managers may not be able to liquidate securities to meet redemption pressures, which may lead to contagion if some segments are liquidity-constrained.

- Securities dealers, under pressure, perhaps, because of a loss of funding liquidity, could face solvency problems if asset prices are depressed significantly below their fundamental values. ${ }^{23}$

- Normally creditworthy nonfinancial borrowers may lose access to short- and long-term funding markets, directly impacting the broader economy.

- During periods of stress, the liquidity and solvency of banks and nonbank financial issuers may be adversely impacted, reducing their ability and willingness to extend credit to the economy.

- Sovereign issuers may lose access to funding where secondary market freezes lead to failures in the primary market.

The rest of this section covers several program design issues: (1) intervention methods; (2) nonrecourse repos; and (3) considerations with regard to exiting from programs.

\section{Intervention Methods}

The response to one-sided markets may require direct intervention by central banks to remove some price risk and mitigate information asymmetries; this can be approached broadly in two ways: (1) reverse auctions; and (2) bilateral on-market interventions. A summary of the issues and the risks involved with each approach is provided in Table 4. Subsequent sections elaborate on the issues with example programs from the GFC provided.

\footnotetext{
${ }^{23}$ Market illiquidity and funding illiquidity reinforce each other through various financial frictions. First, through collateral constraints: when funding liquidity is low, traders reduce positions on high-margin securities thus causing market liquidity to fall (Brunnermeier and Pedersen 2009). Second, through asymmetric information about the quality of assets which causes the offer prices of such assets to be too low and can originate a funding illiquidity event. This, in turn, can exacerbate investors' pessimistic beliefs about asset prices and further decrease market liquidity. See Li and Ma (2016).
} 


\section{Table 4. Comparison of Intervention Methods}

\begin{tabular}{|c|c|c|}
\hline & Reverse Auctions & Direct Purchases \\
\hline $\begin{array}{l}\text { Common } \\
\text { Features }\end{array}$ & $\begin{array}{l}\text { Preannounced schedule operations. } \\
\text { A fixed volume variable rate format- } \\
\text { allowing the market to reveal a clearing rate. } \\
\text { Ex-ante and ex-post transparency is high } \\
\text { With usual central bank counterparts, or with } \\
\text { an expanded list. }\end{array}$ & $\begin{array}{l}\text { Bilateral direct, through a broker or electronic } \\
\text { platform. } \\
\text { Potentially with any market participant. } \\
\text { Discretion/flexibility regarding timing and } \\
\text { intervention size. }\end{array}$ \\
\hline $\begin{array}{l}\text { Appropriate } \\
\text { Circumstances } \\
\text { for Use }\end{array}$ & $\begin{array}{l}\text { With standardized products. } \\
\text { Price discovery is problematic (can tailor } \\
\text { regular small auctions). } \\
\text { Transparency requirements are high. } \\
\text { Short-term instruments where no secondary } \\
\text { markets exist. }\end{array}$ & $\begin{array}{l}\text { Where swift actions are required to respond to } \\
\text { market moves. } \\
\text { When there is a need to by-pass banks, and } \\
\text { target the private sector directly, which can't be } \\
\text { satisfactorily achieved through auctions. } \\
\text { More suited for non-standardized and diverse } \\
\text { instruments. }\end{array}$ \\
\hline Risks & $\begin{array}{l}\text { Collusion between participants. } \\
\text { Not reaching intended market segment if } \\
\text { there is narrow participation eligibility. }\end{array}$ & $\begin{array}{l}\text { Lack of transparency may hinder efforts to } \\
\text { restore market functioning. } \\
\text { Central bank objectives may be misconstrued. } \\
\text { Risks of dealing with unsupervised } \\
\text { counterparties. } \\
\text { Risk of dealing at nonmarket prices in very thin } \\
\text { markets. } \\
\text { Risk of being front-run by counterparty. }\end{array}$ \\
\hline
\end{tabular}

Source: IMF staff.

\section{Reverse Auctions}

Central banks commonly use one-way auctions when implementing monetary policy and when conducting debt management operations on behalf of the government. ${ }^{24}$ With a reverse auction the central bank offers to buy securities, thus adding demand to an unbalanced market. The auctioneer (that is, the central bank) has considerable flexibility in determining the format, including the selection of eligible participants, the securities it offers to buy, the allocation method, and, potentially, limits on prices and quantities. The BOE interventions in the corporate bond market provide an example of how auctions can be used (Box 5).

Auctions facilitate transparency and competition between sellers, thereby aiding price discovery. In settings where there is uncertainty about the asset values, a reverse auction should help reduce that uncertainty as the auction results (if published), provide tangible pricing points that can be useful for the primary and secondary markets - not only in the security that is being auctioned, but also in the wider market. Also, auctions encourage participation because with rules specified in advance, they are competitively neutral - that is, all (eligible) participants have equal information and an equal ability to compete. Two-way auctions are also useful if dealers are reluctant to trade with each other, since the central bank is the counterparty to successful participants in an auction. ${ }^{25}$

\footnotetext{
${ }^{24}$ A one-way auction is where participants can either buy or sell instruments, but not both.

${ }^{25}$ A two-way auction involves participants providing bids and/or offers with the central bank acting as the intermediary by matching all overlapping bids and offers. This overlap occurs where there are bids higher than there are offers. The central bank stands as the counterpart to all successful bids and offers.
} 
There are two main variations of auction format: the authorities will need to decide whether they wish to target a rate or target a quantity - they cannot target both.

- Targeting a rate-fixed-rate, full-allotment. The authorities accept all bids at the announced fixed rate (or spread). This approach is suitable where the intention is to put a ceiling on rates. Here there would need to be confidence that an appropriate rate can be identified, and that they can bear the resultant financial risks given the uncertainties about the volume of securities that they may need to purchase.

- Targeting a volume-variable-rate, fixed-volume. The central bank sets the volume and allows the market to reveal its schedule of supply at different prices. This approach supports price discovery while allowing the central bank to better control its financial risks. With variable-rate auctions, there are two main allocation methods: ${ }^{26}$

- Uniform-priced auctions - all successful bidders are allocated at the same rate, thereby eliminating the winners' curse. ${ }^{27}$ This may be an important consideration in highly uncertain conditions where price discovery is significantly compromised.

- Multiple-price auctions - successful bidders are allocated at the rate at which they bid. This is the more commonly used format.

In perfect market settings, per the revenue equivalence theorem, both formats provide similar outcomes (see Klemperer 1999). However, multiple-price auctions do have the advantage of providing more information on the supply curve and maybe less prone to collusion in imperfect market settings.

The size of the auction matters. Where price discovery is the major issue, then auctions conducted at regular intervals, perhaps in small amounts, would provide reference points for market activity to resume. But auctions need to be large enough to be meaningful and, as much as possible, representative of transactions occurring in the wider market. If auctions are being used to balance the market by removing market risk, then volumes would need to be larger - in particular, large enough to meet a significant portion of the supply of securities in the market, as evidenced by the volumes on offer in the market.

\section{E. Direct Purchases}

When prices are falling precipitously, or for markets for nonstandard instruments, direct purchases might be the preferred intervention route. For central banks in some circumstances, time maybe of the essence for an intervention, and properly designing and conducting auctions may take too long. Direct purchases of securities in secondary markets can represent an appropriate, immediate, and forceful response in times of market stress. Such an approach

\footnotetext{
${ }^{26}$ By design, in a fixed rate auction all successful bidders are allocated at the same rate.

27 The winners curse is where a bidder, in a common value auction (the auctioned item is roughly of equal value to all bidders), pays more for an asset than its intrinsic value, as proxied by the average outcome of the auction.
} 
may be most useful where an auction would not be suitable due to the lack of critical mass in a single instrument (resulting from non-standardized instruments) or a proliferation of issuers or issuance sizes.

Risks associated with direct purchases would seem higher and care is needed to ensure there is sufficient ex-ante and ex-post transparency. With less transparency as compared with auctions, there are risks that participants may not understand the intent of central bank actions or the extent of the intervention, exacerbating market uncertainty rather than diminishing it. Further, in thin markets, a participant may get lucky (perhaps because of a transaction through a broker) and deal at a price with the central bank that others cannot deal at. The question of competitive neutrality (ensuring a level playing field for all participants) may thus arise, something which is not an issue when an auction is employed. During periods of stress, the balance of risks for direct interventions would point to the need for more transparency and neutrality across participants, both issues which favor the use of auctions; therefore, the bar for using direct bilateral interventions should be considered as relatively high.

\section{Box 5. Auctions-Fixed Rate: Bank of England Commercial Paper Program}

In February 2009, the BOE introduced a commercial paper purchase program aimed at restoring the flow of credit to the U.K. corporate borrowers (see Figure). The program had the following key features:

Issuer eligibility - Sterling denominated issuance of nonfinancial companies that make a material contribution to the U.K. economy. CP was initially required to be of a maturity of three months but ultimately adjusted to be of any maturity from one week to three months.

Pricing - tiered margin over overnight indexed swap (OIS) according to issuer credit rating: A1/P1/F1 75 basis points (bps), A2/P2/F2 $125 \mathrm{bps}, \mathrm{A} 3 / \mathrm{P} 3 / \mathrm{F} 3300 \mathrm{bps}$ for primary market issues. The higher of the above or the initial issue spread for secondary market purchases plus a 25-bps fee.

Counterparties - dealers acting as principal and secondary market holders authorized for the purposes of the Financial Services and Markets Act.

Facility structure - window open daily between 10 a.m. and 11 a.m. for purchases at the fixed rates noted above. No individual results were published each day - a weekly summary of volumes purchased was released each week.

Risk management arrangements-BOE applied an issuer limit that was known only to the issuer.

The program was very successful and saw significant interest for the first few months of operations when credit spreads were relatively wide. Issuance volumes remained on a downward

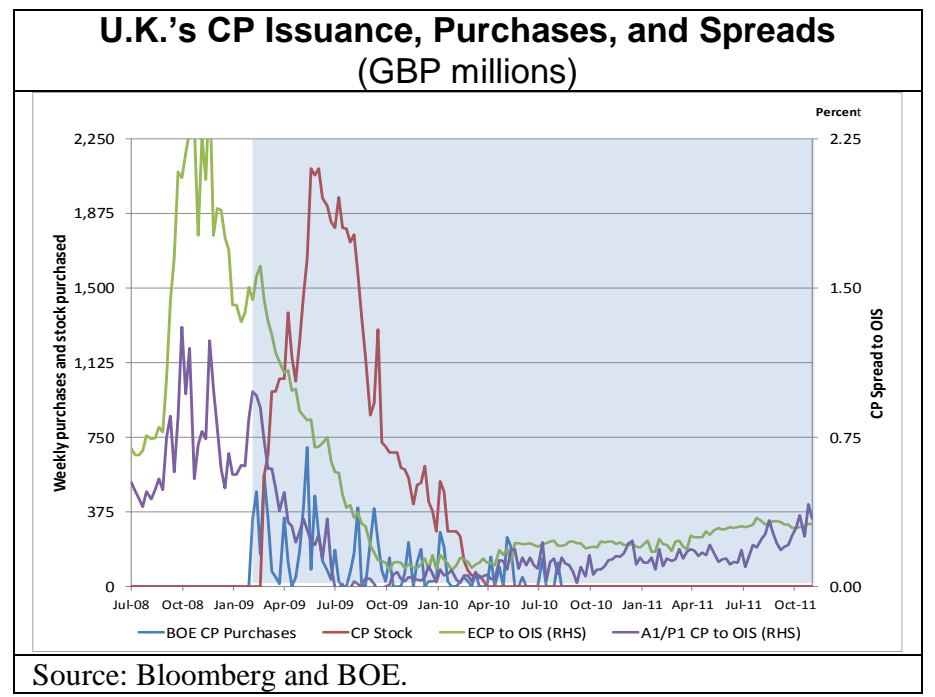
trend as they were transitioning to a lower steady-state issuance level. The pricing was more expensive than normal spreads, which aided exit as issuers were eventually able to find demand in the market at better rates than at the BOE facility. The BOE announced that the market would receive 12 months' notice of the closure of the facility. The facility was closed to new issuance in November 2011. 


\section{Box 6. Auctions-Variable Rate: Bank of England's Corporate Bond Program}

In March 2009, the BOE commenced a regular program of reverse auctions of U.K. corporate bonds with the objective of improving price discovery, which had become impaired as corporate bond spreads had widened significantly in the wake of the failure of Lehman Brothers in late 2008.

Initially, there were three auctions per week. When sales were introduced, two purchase operations and one sales operation were conducted per week, which was later reduced to one purchase and one sales operation. The securities included U.K. sterling-denominated unsubordinated corporate bonds of a credit rating of BBB- or higher. Eligible bonds were of at least one year to maturity and of a minimum issue size of $£ 100$ million. The auction size was calibrated such that the BOE stood ready to purchase up to $£ 2$ million or $£ 5$ million pounds of each eligible bond (depending on the outstanding volume of the security) at least once a week. Eligible issuers were companies with operations that made "a material contribution to economic activity in the U.K." This encompassed nonbank financial companies excluding building societies.

Eligible auction participants included wholesale market making firms that were BOE counterparties in its open market operations.

Uniform price auctions were used; hence, all successful offers of bonds were satisfied at the minimum clearing spread. All purchases were subject to a minimum clearing spread for each security purchased. All offers were specified as a spread to a reference U.K. gilt.

No limitations applied to the volume of securities that could be purchased from a particular dealer, although each dealer could only submit three offers per security.

The BOE imposed a limit on the total volume of each line of security purchased so as to not unduly undermine liquidity in the bonds concerned. This limit was not disclosed to the market.

Auctions to sell bonds purchased began in January 2010, once market liquidity improved. In June 2013, the BOE announced that regular auctions would cease but the facilities would remain open and auctions reactivated should market conditions warrant. The scheme was formally closed in August 2016 following the announcement of the new Corporate Bond Purchase Scheme.

The program proved successful, with credit spreads falling after an early burst of activity in March 2009. Smaller purchases were made in early 2012 when euro-area pressures reemerged, but concerns eased relatively quickly. By the time regular auctions ceased, few transactions were occurring, suggesting that the BOE's minimum spread was effective in channeling transactions back to the market.

\section{U.K. Corporate Bond Spread to Gilts: BoA Merrill Lynch Sterling Securities Corporate Index}

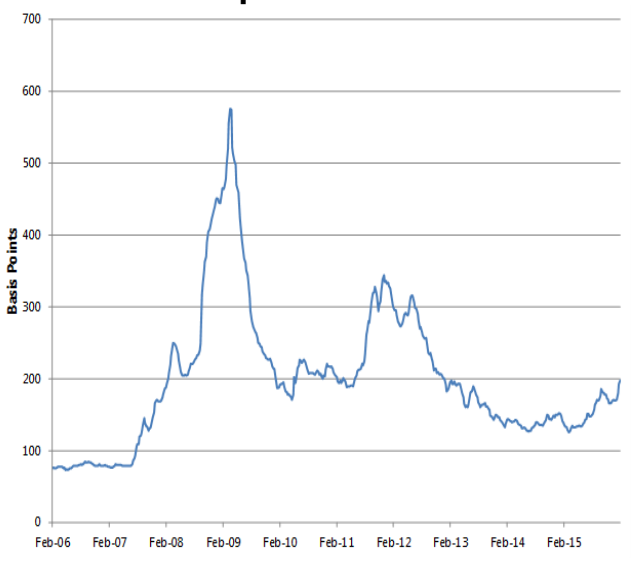

Source: Bloomberg

\section{BOE Corporate Bonds Purchased and Sold}

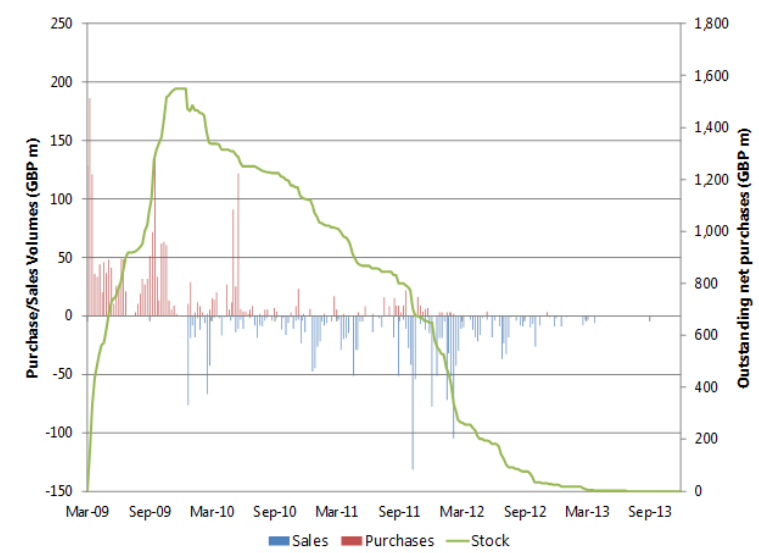

Source: BOE 


\section{F. Non-recourse Instruments}

Where funding and market liquidity are clearly deteriorating, more complex instruments may be designed to address both issues. Funding and price insurance (providing protection against falling prices) can be combined into a single instrument, as was used by the Fed with nonrecourse lending during the GFC. With standard collateralized lending and repos, the borrower remains fully exposed to changes in the value of the collateral.

Nonrecourse lending could be particularly useful to address fire sales. Where intermediaries are experiencing funding problems or are forced to sell to draw a line under potential losses, central banks can offer funding with an option that if the value of the collateral falls beyond a certain point, then the borrower is relieved of his obligation to repurchase the collateral, thereby limiting downside risk.

Pricing of such instruments should aim to incentivize participation and minimize adverse selection and moral hazard while seeking to avoid undue risk to the central bank. The pricing and risk mitigation measures associated with recourse repos is quite straightforward, at least in normal times; the rate may be determined through an auction while haircuts are set on identified risk tolerances and value-at-risk metrics. The pricing of nonrecourse repos should seek to encourage broad participation, for instance, during periods of fire sales. While option pricing approaches should be used as much as possible, since the central bank is selling a put option, pricing the risk of tail events where few prices have been observed will likely mean that a good deal of judgment may be required, aided by feedback from market participants.

The pricing for non-recourse lending could involve a number of additional costs to manage and compensate for the additional risks involved in recourse lending; such costs might include, for example, a higher interest rate, a fee, or a higher haircut. The central bank needs to be compensated for providing this optionality as it may end up owning the collateral and incurring losses if the collateral then falls further in price. If the value of the collateral does not fall below its original valuation minus the haircut, then the borrower repays the repo and takes back the collateral — which is a best-case scenario, since it would indicate a reduction in market risk, with the central bank avoiding having to take in the collateral.

Setting the appropriate haircut is especially important, particularly where a wide range of securities and issuers may be involved. Too large a haircut might inflict (perceived) excessive losses on investors and so fail to prevent the risk of a fire sale; too low a haircut puts excessive risk on the authorities and increases moral hazard. But while difficult, the pricing may be easier than if the central bank were to act as "investor of last resort" by purchasing the assets outright. The Fed incorporated nonrecourse elements into the program to stem fire sales resulting from redemption pressures faced by MMMFs (Box 7) and when end-investors pulled back from ABS markets, severely restricting the flow of credit. 


\section{Box 7. The Federal Reserve's AMLF to Address Fire Sale Risk}

In the face of severe redemptions pressures faced by MMMFs and resultant fire-sale dynamics the Fed had to respond quickly. Because the Fed cannot directly purchase $\mathrm{ABCP}$, it established a program of lending to financial institutions against eligible ABCP. The lending was in the form of nonrecourse repos, which effectively provided a Fed guarantee on this short-term paper. Financial institutions were able to buy the ABCP from eligible MMMFs at amortized cost and fund them at the primary credit rate. Given the positive cost of carry, institutions were incentivized to take part.

The eligible institutions were U.S. depository institutions, U.S. bank holding companies, and the U.S. branches and agencies of foreign banks.

The ABCP had to (1) be purchased from MMMFs (operating under Securities and Exchange Commission Rule $2 \mathrm{a}-7)$ that had experienced net redemptions exceeding 5 percent of assets under management in a single day, or 10 percent in a period of 5 business days or less; (2) be issued by a U.S. issuer in U.S. dollars;

(3) have a minimum credit rating of A1/P1; and (4) be purchased on or after September 19, 2008.

Loans provided were for the maturity of the $\mathrm{ABCP}$, to a maximum of 120 or 270 days for depositary and nondepository institutions, respectively. There were no haircuts, fees, or additional spreads to be paid, while the program was nonrecourse to the borrowing banks, which in effect guaranteed repayment of the $\mathrm{ABCP}$. These transactions did not incur any additional capital charges.

The program was launched September 19, 2008 and was effective, as evidenced by the containment and ultimate reversal in spreads. The size of the program peaked at US\$147 billion, a time at which the spread between ABCP and AA-rated CP peaked at over four percentage points (see Figure). Thereafter, the spread diminished rapidly towards pre-crisis levels.

\section{G. Special Purpose Vehicles to Limit Central Bank Risks and Mitigate Moral Hazard}

Some major central banks during the GFC - the BOE and the Fed, for example - did not take exposures directly onto their balance sheet and instead held assets in a separate entity. In the case of the BOE, all assets purchased, including those purchased for monetary policy purposes, were held in the Asset Purchase Facility (APF), a subsidiary company of the BOE. In the case of the Fed, legal restrictions on the securities it could purchase meant that it set up vehicles to which it lent, and which in turn purchased the targeted securities. 
The use of publicly established separate vehicles facilitates the ring fencing of the assets purchased and allows for clarity about risk-sharing arrangements with the sovereign. The U.K. Treasury fully underwrote the assets held in the APF by promising to indemnify the BOE for any losses incurred. In some U.S. programs, the special purpose vehicle did not entail risk-sharing with the U.S. Treasury (for example, the Commercial Paper Funding Facility (CPFF) while in others it did (for example, the Term Asset-Backed Loan Facility (TALF).

Privately incorporated special purpose vehicles (SPVs) also served a useful purpose in ensuring that investors were incentivized to screen asset quality, thus minimizing moral hazard. When securitized asset markets froze in the U.S. in late 2008, the Fed incentivized participants to reenter the market by providing secured funding to an entity which purchased securities from the loan originator. The Fed is not allowed to directly purchase assets that are not eligible in its normal operations. Participation was encouraged through advantageous funding arrangements which matched the duration of the underlying securities. Moral hazard or the adverse selection problem was dealt with through the haircut applied to the loan-thus, meaning the investor took the first loss. Another feature of this program was its nonrecourse feature, which limited the investor's downside (as discussed in the previous section).

\section{H. Considerations for Effectiveness and for Exit}

Essential to the success of a program is that authorities demonstrate both an understanding of the problem and a commitment to deal with it. An open-ended program, in terms of time and transaction volumes, sends the strongest message of central bank commitment. Conversely, if a central bank were to announce constraints within which the market considered the problems not resolvable, then market conditions could potentially worsen. Tentative limits or points at which the central bank would review the program could provide useful guidance to market participants, while not undermining perceived commitment. In a number of programs during the GFC (such as the BOE's CP and bond programs), flexible guidance was provided to demonstrate commitment while not tying the authorities to fixed times or quantities.

Considerations for exit are also important:

- Ending the program. Programs should end when market conditions that brought about their introduction have been satisfactorily addressed. This would mean that the flow of credit through the identified markets had been satisfactorily restored (which does not mean that pre-crisis levels would had to have been attained) and/or the risk of fire sales had largely passed (evidenced, perhaps, by lower price volatility and a narrowing of spreads). Programs with previously announced time or volume limits could be shut down early as a sign of confidence that markets had normalized; equally open-ended programs can also be closed at such points. Pricing also matters, as many programs involved prices or funding rates set by the central bank. Generating conditions that incentivize participants to resume market-based activities is key. In many cases, central banks set prices or funding rates at levels that were sufficient to incentivize banks, investors, or broker-dealers to participate. Funding rates that are set too low could result in the central 
bank buying more securities than it desires, while if rates are set too high, few if any transactions might take place, thereby impeding market recovery. The right level is one which caps rates and then results in market activity being conducted below such rate caps, after which point the central bank program becomes less important. A good illustration of this is the Fed's TALF where ABS markets were resuscitated well short of the program limit (US\$70 billion as against a limit of US\$1 trillion).

- Unwinding the program. Unwinding the program involves restoring the central bank balance sheet to its pre-crisis size and risk profile. Programs targeting short-term instruments (for example, $\mathrm{CP}$ markets) will naturally unwind relatively quickly once the program is stopped. In the case of longer-term instruments, the choice is to either allow the assets to roll off, in which case normalization may take some time, or to sell the securities prior to maturity. Here the context matters, as in some cases (notably with the Fed) the assets were loans made to SPVs, which in turn purchased the targeted securities - in this case, there is no option for early or discretionary balance sheet unwind. Where securities are taken onto the central bank balance sheet, sales prior to maturity can be considered, bearing in mind any commitment made at the commencement of the program - which may have been to hold to maturity (for example, ECB's Securities Market Program (SMP)). Here the central bank would need to carefully consider the risks of rekindling the type of market conditions that brought about the need to intervene in the first place. It would seem that erring on the side of caution is most sensible when considering such sales, after a period of significant market dysfunction. ${ }^{28}$

\section{IMPLEMENTATION}

\section{A. Coordination with Other Crisis Management Policies}

Actions to support securities markets should be considered as part of a broader crisis management package because resuscitating key markets may not be sufficient to restore financial stability. Narrowly defined, the intent of intervention in securities markets is to address the root cause of problems in the identified segments. However, the likelihood is that threats to financial stability will arise across the financial sector with spillovers from one segment to others, therefore requiring a multipronged response. For example, support provided to commercial paper markets may help specific issuers in the short term, but if systemic risks in the banking system are left unaddressed, any benefit to those issuers could be short lived if a run on the banking system were to unfold (see Appendix IV for a summary of LOLR issues). Monetary and fiscal policies too would likely have a role to play, as they did during the GFC, to counter sharp falls in consumer confidence and consumption. Emphasized, however, is the need for coordination across the different policies when faced with risks of a systemic dimension.

\footnotetext{
${ }^{28}$ The BOE's corporate bond program is a good example of where bonds were sold prior to maturity. The objective of this program was to promote price-discovery and so it was always expected that the BOE would be selling bonds as well as buying (Appendix III).
} 


\section{B. Monetary Policy Impact}

Central banks should ensure that emergency actions do not undermine the desired stance of their monetary policy. Most support actions - except perhaps collateral swaps - will increase the monetary base and, depending upon the design of the operational framework, may also put downward pressure on short-term interest rates. Periods of severe disruption in securities markets will likely reflect more widespread financial stresses and economic weakness, which indeed calls for easier monetary policy. The extent to which securities market support is required may, however, ease monetary conditions more than is desired, given the outlook for inflation. In such cases, the central bank should sterilize some of the marginal liquidity and/or ensure that interest rates do not fall below targeted levels. The options for sterilization would include, but should not be limited to, selling short-term government securities, either of its balance sheet or under an agency arrangement with the ministry of finance, or selling its own securities. To support short-term interest rates at desired levels, most operational frameworks incorporate an interest rate floor where the central bank pays interest on reserves, below which interbank rates generally do not trade. ${ }^{29}$

\section{Risk Management and Operational Considerations}

Some central banks have legal constraints on the types of securities they can purchase, the structure of the program, or the types of collateral they can take, or even on their ability to deal with non-bank counterparties. ${ }^{30}$ Hence, there may be limits to the types of interventions possible, and legally permissible structures may have to be employed.

Some instruments being purchased or accepted as collateral may require prepositioning or outside support to administer. Many central banks routinely deal in only plain or vanilla-type securities whereas intervention could involve securities that are more complex and risky. The central bank may therefore need to employ the services of specialist private sector institutions as custodians, valuation agents, providers of trading services, and asset or risk managers. ${ }^{31}$ Alternatively, some effort may be required to pre-position resources and expertise to facilitate the management of intervention operations in nonstandard markets or securities. $^{32}$

\footnotetext{
${ }^{29}$ Supporting interest rates in the midst of the GFC was indeed a concern for the Fed. Only in October 2008 was it granted the authority to pay interest on reserves under the Emergency Economic Stabilization Act of 2008.

${ }^{30}$ As examples, under Article 18.1 of the Statute of the European System of Central Banks, the ECB is prevented from purchasing government bonds in the primary market, and the Fed can only purchase outrightor use as collateral-U.S. Treasury bonds, agency bonds, and agency mortgage bonds.

${ }^{31}$ The Fed used an external manager for its purchases of agency securities during the GFC and agents for TALF operations with nonbank counterparties.

32 The BOE invested considerable resources to upgrade its risk management architecture to cater to the much wider range of collateral taken in its liquidity provision operations during the GFC as well as its corporate bond
} 
The central bank should mitigate risks in lending and asset swap operations by being fully collateralized with adequate haircuts and margining provisions. The only exception is where the operations are conducted through nonrecourse repos (as by their nature, discussed earlier, they do not allow for margining). To mitigate the market risk associated with the assets acquired but not the credit risk central banks can book the securities on a hold-to-maturity basis. $^{33}$

\section{Transparency, Communication, and Accountability}

FX intervention is relevant when considering ex-ante transparency (Enoch 1998). It has been accepted that FX interventions should be undertaken covertly in some circumstances, including where the central bank (1) did not wish to signal involvement as it considered the market imbalance to be temporary; (2) was unsure of its ability to address the situation, and as such actions carried high risks to their credibility; or (3) thought that having its presence known in the market may exacerbate the problem. However, such concerns do not translate to intervention in securities markets where the stability of the entire financial system is at risk. The central bank needs to demonstrate an understanding of the problem and a willingness to deal with it. Poor communication may exacerbate the problem, requiring prolonged and riskier interventions. ${ }^{34}$ The analogue here with FX intervention is that ex-ante transparency is helpful where there is uncertainty about the policy stance.

The notion that central banks are accountable to the public and their stakeholders is important when considering how much detail central banks should provide on the interventions and when to provide it. Such a decision is not clear cut, as too much detail provided too soon could undermine efforts to restore stability.

\section{E. The Role of the Government}

Central banks should always be sufficiently capitalized to enable them to meet their objectives during normal times, while indemnities may be needed to address crisis-related risks (Stella 2002). In crisis times, central bank intervention may require actions greater than the size of the central bank's capital base, and therefore indemnities, or commitments to replenish central bank capital, are needed when the central bank perceives the risks - whether counterparty, collateral, or length of support - to be greater than its defined tolerance level.

Where the government is involved, it may be preferable to use off-balance sheet vehicles. As noted earlier, such a structure allows the central bank to preserve its autonomy from the Treasury, with the Treasury directly covering some or all of the losses and receiving a

program. The ECB used outside entities to advise on the design and implementation of its securitization program and also used external firms to acquire certain securitizations on behalf of the euro area.

33 This is the approach taken by the ECB, for example.

${ }^{34}$ Altavilla and others (2015), citing different literature covering the Fed and BOE purchase programs, note that the main impact of purchase programs occurs at the time of program announcement, while the effect of actual purchases is rather limited. 
commensurate amount of any profits. This also allows for a clearer identification of the true fiscal cost associated with the intervention. By requesting an indemnity, the central bank is essentially involving the government in the intervention decisions. The assumption here is that the government recognizes the importance of maintaining financial stability and does not object to taking on some of the risks of central bank intervention, and it is in a position to do so (that is, it is solvent).

\section{F. Stakeholder Coordination}

Intervention may need to take place within a tight time frame, therefore the preparation of internal guidelines and action plans is highly recommended-similar to those applicable for LOLR. The decision-making process, and the roles and responsibilities for internal and external stakeholders involved, should be defined ex-ante. ${ }^{35}$ Regular communication and coordination between the central bank and securities supervisors regarding the state of markets, intermediaries, and infrastructures is a critical element for any emergency support function to be effectively implemented.

\section{Preparedness}

Robust coordination arrangements between the different stakeholders are essential for the central bank to be able to perform its emergency support function when required. Key determinations include the following:

- The decision-making process. This could be best established through an intra-stakeholder committee, involving at least the governor, the supervisor, and the minister of finance. This committee should meet regularly_-perhaps twice yearly_- to discuss market developments, with more frequent meetings held as particular issues become more acute. The committee could base its assessment on the work provided by the operational working group responsible for anticipating, preparing, and monitoring the interventions. ${ }^{36}$ A record of these meetings should be kept, which would help as part of the ex-post accountability process.

- Preparation of key structural elements. For example, SPVs could be established and associated accounting and governance arrangements could be formalized and put on standby, ready to be activated. Levels of government support should be formalized and be available when needed. Furthermore, counterparty legal agreements should be

\footnotetext{
${ }^{35}$ In many countries, a national crisis management committee, chaired by the Minister of Finance, is responsible for the development and maintenance of the crisis management planning framework and preparation of crisis management plans and simulation exercises, along with decisions on LOLR involving government resources.

${ }^{36}$ Some terms of reference for this group should cover issues such as membership, expected output, and frequency of meetings. It would be expected that at a minimum, markets supervision, financial stability, market operations, monetary policy, and the payments and accounting areas of the central bank would be represented in this group.
} 
prepared, such as those concerning nonrecourse loans, which could be fine-tuned closer to the time of intervention.

- Regular updates and scenario analyses. The operational working group could provide regular updates on those markets deemed to be systemically important, highlighting any particular instances of possible dysfunction along with the possible reasons behind these occurrences. It may also be helpful to prepare scenario analyses examining elements such as the different types of market failure, the likely triggers for intervention, and in what format the authorities' response should best be structured. Moreover, any such analysis could also focus on the potential for contagion if the central bank does not provide support.

- End-to-end testing. Simulations should be prepared, possibly also by the operational working group (and approved by the intra-stakeholder committee) to test the emergency procedures and preparedness, and identify gaps and improve internal policies and guidelines.

\section{Ongoing monitoring}

Continuous coordination and information sharing within stakeholders and between stakeholders is also required. The operational group should on a regular basis provide updates to the parent committee on topics such as an assessment of program performance, changes in market conditions, and justifications for increased or reduced intervention, along with the structure and timing around program exit so that financial stability is not undermined. ${ }^{37}$

\section{CONCLUSION}

In some circumstances, emergency support of securities markets may be needed to maintain financial stability, the key elements of which are (1) ensuring that credit flow is not unduly disrupted resulting in a detrimental impact on the real economy; and (2) mitigating the risk that financial asset fire sales could threaten solvency in important parts of the economy. Well-functioning securities markets are also important to the effective transmission of monetary policy in many countries. Actions taken by some central banks during and since the GFC highlight the need for close monitoring of securities markets, early identification of problems, and, in the event that the problems threaten financial stability objectives, welldesigned programs targeted at the identified problems.

The bar for central banks to support securities markets should be set high, with actions undertaken within a broad framework recognizing country/market-specific characteristics. This paper provides guidance to central banks on how to shape an emergency support

\footnotetext{
${ }^{37}$ As part of this process, the operational working group should prepare a schedule of haircuts to be applied where repos or assets swaps are the instruments of choice.
} 
strategy based on a clear understanding of the links between financial and price stability and securities markets. ${ }^{38}$ In general, actions should follow these guidelines:

- First, actions should be targeted at markets that are normally liquid, relatively large and important (that is, interconnected), and of high credit quality.

- Second, actions should be triggered only when the financial stability and monetary policy transmission objectives are under threat, which is more likely when there are unusually large changes in trading activity and prices in the identified markets that are difficult to explain fully by changes in the fundamentals. Intervening too soon may give rise to moral hazard and could impede markets from moving to a new equilibrium, while delaying a response may allow disruptive market dynamics to take hold and be costlier in the long run.

- $\quad$ Third, actions should be designed to address the underlying problem while incentivizing participants to reenter the market and minimizing the risks to the central bank.

It is crucial that official actions (words or deeds) do not generate expectations that participants will be bailed out in the event of market disruptions - that is to say, the potential for moral hazard must be minimized. As well as ensuring a high bar for action, moral hazard will be minimized by not publicly pre-committing to support markets.

Focus is also needed on ex-ante (preventative) measures to incentivize self-insurance of liquidity risks. Emerging risks posed by changes in market infrastructures-for example, electronic trading - and the rise of the asset management sector highlight the need for appropriate liquidity regulation as well as the need to have the necessary liquidity management tools in the hands of asset managers to deal with periods of stress. Sound regulation and supervision are a first line of defense, but there is always a risk of a tail event resulting in a freeze of key markets, and hence the need to consider official intervention. The interaction between ex-ante regulation and supervision and the various modalities of official support to securities markets is an important topic that warrants further analysis and discussion.

Emergency support to securities markets alone would be unlikely to succeed unless coordinated within a broader crisis management package. The likelihood is that threats to financial stability would not be confined to the functioning of the securities markets, and even well-designed programs may at best be only partially effective. Therefore, restoring market confidence may require a forceful and coordinated response to address concerns about the soundness of a range of financial institutions and a need for policy stimulus to support aggregate demand.

\footnotetext{
${ }^{38}$ Providing specific and tailored guidance, however, is beyond the scope of this paper.
} 


\section{Appendix I. Market Failures-Revisiting the Theory}

The interventions of policymakers in markets - through regulation or other forms of official intervention such as the one discussed in this paper - can be justified by the presence of market failures. Under a market failure, markets cannot deliver the best outcome. During a market freeze, official intervention can, in theory, make at least some agents better off without making anyone worse off, simply by creating the conditions for trade to resume and allowing investors to reap the benefits from trade. There are three sources of market failures which can suddenly deplete market liquidity and lead to a market freeze: (1) asymmetric information; (2) incomplete markets; and (3) externalities.

An increase in the amount of asymmetric information - differences among potential traders in the knowledge about the fundamental value of assets — can trigger market liquidity crises and market freezes. In simple terms, when some traders are better informed than others, there is a chance that the market maker will end up on the wrong side of trade by buying or selling from someone who is more informed than she is. As a consequence of this adverse selection problem and of uncertainty about the appropriate fundamental-driven asset prices, market makers reduce the provision of market liquidity.

A second market failure relevant for market liquidity crises is one of incomplete marketssome risks cannot be hedged. In normal times, market-makers provide liquidity insurance to investors by facilitating the conversion of assets into cash before maturity (Davis 1994). However, investors cannot buy insurance against large liquidity shocks. Thus, when facing increased uncertainty about future economic prospects or cash flows, some investors must sell some of their less liquid assets and put downward pressure on prices.

A final market failure is the existence of externalities associated with selling behavior. Financial firms accumulated large exposures to liquidity risk in the run up to the 2007/09 financial crisis but failed to internalize the repercussions on asset prices of forced sales caused by higher uncertainty or risk perceptions (Acharya, Krishnamurthy, and Perotti 2011). The ensuing drop in asset prices reduces the value of existing collateral, worsens funding conditions, and causes more sales. Under these conditions, market making declines because the one-way market erodes dealers' capital base and increases inventories beyond desired risk exposures.

Market failures associated with market liquidity crises are not mutually exclusive and can reinforce each other. On the one hand, the absence of insurance markets against some aggregate risks can sometimes be explained with severe information asymmetries between prospective buyers and sellers of insurance. On the other hand, when financial institutions and traders cannot insure against aggregate risks (incomplete markets), a typical response is to hoard liquid assets and become less likely to make uninformed trades, thus worsening the adverse selection problem (Malherbe 2014). 


\section{Appendix II. Foreign Exchange Intervention Channels}

There is an extensive literature on FX intervention, much of which is relevant to securities markets. Early empirical studies tended to conclude that FX intervention had little or no impact on exchange rates, although from the 1990s onwards more evidence of the effectiveness of intervention was found as data improved and new channels of influence were examined. ${ }^{1}$ This literature shares common strands for securities markets, including the motives for intervention, channels of influence, and intervention indicators and techniques.

The objective of combating excessive volatility and exchange rate overshooting has an analogue to securities markets. Moreno (2005) discusses the motivation for FX intervention and identifies the maintenance of financial stability as being a key objective, which is analogous to the motivation for intervention in securities markets.

The signaling, portfolio balance, and microstructure channels are also likely important to securities markets interventions. A key channel of influence for FX intervention effectiveness is the signal that intervention provides about future monetary policy and the equilibrium exchange rate (Dominguez and Frankel 1993; Ishii and others, 2006), which is similar to the asymmetric information motivation for securities market intervention noted in Appendix I. Similarly, with the portfolio balance channel, intervention changes the currency composition of the market's portfolio prompting supportive follow-on transactions, is important in the securities market context. Finally, interventions aimed at influencing exchange rates via the microstructure of markets and order flow (see Evans and Lyons 1999, Dominguez 2003, and Eckhold and Hunt 2005) have similar applications in securities markets.

Volatility indicators and measures of order flow imbalance are relevant. Canales-Kriljenko, Guimaraes and Karacadag (2003) discuss the considerations in an FX intervention context and focus on indicators such as an acceleration in exchange rate changes, increasing volatility, widening bid-offer spreads, and changes in the composition and magnitude of market turnover as being key indicators of possible market dysfunction. This work emphasizes that assessing exactly when markets have become dysfunctional is challenging and is state- and market-dependent, and thus not amenable to all-encompassing rules of thumb. These observations are all relevant in the securities market context.

\footnotetext{
${ }^{1}$ See Rogoff (1984) and Henderson and Sampson (1983) for early empirical analysis and Dominguez and Frankel (1993) for an overview of the early work and later literature finding more promising empirical results.
} 


\section{Appendix III. Past Programs to Support Securities Markets}

Many countries introduced programs to support securities markets during the global financial crisis (GFC). The programs were aimed at supporting the flow of credit, preventing or addressing fire-sale dynamics and in some cases supporting the transmission of monetary policy. The individual programs were specific to the country setting, particularly, with regard to the targeted markets, the legal constraints faced by the central bank and, to a lesser degree, political considerations.

In the U.K., the corporate bond market was a key credit channel, as was the structured credit market in the U.S., while commercial paper markets in both countries were vital. A significant increase in corporate credit spreads in the U.K. was the trigger for the corporate bond program, while the Fed focused on the structured credit markets via the Asset-Backed Commercial Paper Money Market Mutual Fund Liquidity Facility (AMLF) and the Term Asset-Backed Loan Facility (TALF). In both countries, access of corporates to credit was deemed highly impaired, leading to the commercial paper program in the U.K. and the Commercial Paper Funding Facility (CPFF) in the U.S.

The key features of the programs are outlined in the following Table. A common feature was the nonrecourse element which limits risks to the private sector market participants. ${ }^{1}$ Another important property shared by many programs is that support for one market implied support for another, or for institutions involved in investing, or in the origination of the affected securities. An example is the support that banks received via the CPFF, when a commercial paper issuer's ability to receive financing through the CPFF reduced the possibility that the issuer would draw on its bank backup credit lines.

The use of intermediary vehicles was also common. In the case of South Korea, the fund that conducted the intervention enabled the cooperation of the public and the private sectors in a jointly financed venture. In the U.S., special purpose vehicles (SPVs) were used to enable the Fed to provide loans to an entity that could purchase, or take in assets as collateral that the Fed itself was not allowed to own outright. The third-party structure made it easier to use outside entities as agents, asset managers, and custodians.

\footnotetext{
${ }^{1}$ Outright asset purchases are nonrecourse by definition.
} 
Table. Summary of Main Features of Selected Intervention Programs

\begin{tabular}{|c|c|c|c|c|}
\hline \multicolumn{5}{|c|}{ Table. Summary of Main Features of Selected Intervention Programs } \\
\hline $\begin{array}{c}\text { Facility } \\
\text { (Start Date) }\end{array}$ & Support Provided to & Intermediaries & Objectives & Main Features \\
\hline $\begin{array}{l}\text { Securities Market } \\
\text { Program (Euro area) } \\
\text { (May 2010) }\end{array}$ & $\begin{array}{ll}- & \text { Selected euro area } \\
\text { sovereign bond markets } \\
\text { - } & \text { Euro area sovereigns }\end{array}$ & $\begin{array}{l}\text { Market makers eligible to } \\
\text { participate in Euro system } \\
\text { monetary policy operations }\end{array}$ & $\begin{array}{l}\text { Allow monetary transmission to } \\
\text { work in the selected markets } \\
\text { - Support the easing of funding } \\
\text { conditions } \\
\text { - Ensure depth and liquidity in those } \\
\text { markets }\end{array}$ & $\begin{array}{l}\text { - ECB purchased bonds in the secondary market } \\
\text { - Credit risk: High }\end{array}$ \\
\hline $\begin{array}{l}\text { Covered Bond Purchase } \\
\text { Program } \\
\text { (Euro area) } \\
\text { (July 2009) }\end{array}$ & 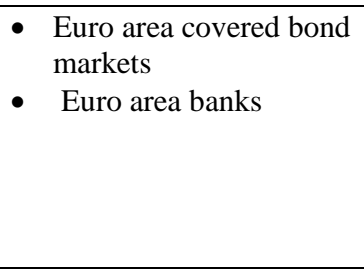 & $\begin{array}{l}\text { Market makers eligible to } \\
\text { participate in Euro system } \\
\text { monetary policy operations }\end{array}$ & $\begin{array}{l}\text { Improve market liquidity in } \\
\text { the covered bond markets } \\
\text { - Encourage the easing of credit } \\
\text { conditions } \\
\text { - Support banks that issued covered } \\
\text { bonds } \\
\text { - Spur credit growth }\end{array}$ & $\begin{array}{l}\text { - } \\
\text { ECB purchased bonds in the primary and } \\
\text { - Minimum quality and outstanding requirements } \\
\text { - } \text { First stage (CBPP 1) limited to } € 60 \text { billion } \\
\text { - } \text { Credit risk: High }\end{array}$ \\
\hline $\begin{array}{l}\text { Secondary Market } \\
\text { Purchases of GSecs } \\
\text { (India) } \\
\text { (August 2013) }\end{array}$ & Government bond market & Market makers & $\begin{array}{l}\text { Reduce yields in the longer part of the } \\
\text { curve }\end{array}$ & $\begin{array}{l}\text { - } \text { Purchases took the form of OMO auctions } \\
\text { - } 10 \text {-year yields fell by } 51 \text { bps after announcement }\end{array}$ \\
\hline $\begin{array}{l}\text { Bond Market } \\
\text { Stabilization Fund } \\
\text { (Korea) } \\
\text { November 2008) } \\
\end{array}$ & $\begin{array}{l}\text { - } \mathrm{CP} \text { and corporate bond } \\
\text { markets } \\
\text { - } \mathrm{CP} \text { and corporate bond } \\
\text { issuers } \\
\end{array}$ & Market makers & $\begin{array}{l}\text { Improve corporate bond market } \\
\text { liquidity } \\
\text { - Allow the } \mathrm{CP} \text { and corporate bond } \\
\text { markets to function }\end{array}$ & $\begin{array}{l}\text { - The Fund was set up by BOK in conjunction with } \\
\text { insurers, and other institutional investors } \\
\text { - Credit risk: High }\end{array}$ \\
\hline $\begin{array}{l}\text { BPAs Repurchase } \\
\text { Auctions (Mexico) } \\
\text { (November 2008) }\end{array}$ & $\begin{array}{l}\text { - } \text { Mutual fund } \\
\text { - } \text { Bond markets }\end{array}$ & & 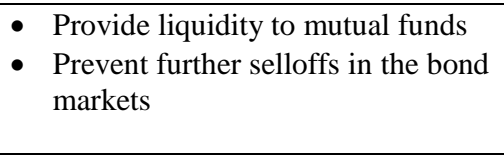 & $\begin{array}{l}\text { - The Bank of Mexico offered to buy up to } \\
\text { MXN150 billion of bonds issued by the deposit } \\
\text { insurance agency } \\
\text { - MXN146.7 billion of this amount was utilized }\end{array}$ \\
\hline $\begin{array}{l}\text { Commercial Paper } \\
\text { Program (U.K.) } \\
\text { (March 2009) }\end{array}$ & $\begin{array}{ll}\text { - } & \text { CP market } \\
\text { - } & \text { CP issuers }\end{array}$ & None & $\begin{array}{l}\text { - Reduce spreads in the CP market } \\
\text { - Allow the primary CP market to } \\
\text { function }\end{array}$ & $\begin{array}{l}\text { - } \text { BOE purchased newly issued CP in reverse } \\
\text { auctions } \\
\text { - Minimum quality requirement } \\
\text { - Issuers had to contribute materially to the U.K. } \\
\text { economy } \\
\text { - Penalty rates were applied } \\
\text { - BOE functioned as an agent for the Treasury: } \\
\text { - Treasury indemnified BOE against losses }\end{array}$ \\
\hline $\begin{array}{l}\text { Corporate Bond Purchase } \\
\text { and Sale Program (U.K.) } \\
\text { (March 2009) }\end{array}$ & $\begin{array}{l}\text { - Corporate bond market } \\
\text { - Corporate bond issuers }\end{array}$ & Market makers & $\begin{array}{l}\text { - Reduce spreads in the corporate } \\
\text { bond market } \\
\text { - Stimulate new issuance of } £ \\
\text { corporate bonds } \\
\text { - Trigger portfolio rebalancing into } \\
\text { other assets }\end{array}$ & $\begin{array}{l}\text { - BOE purchased bonds trading in the secondary } \\
\text { market in reverse auctions } \\
\text { - Minimum quality requirement } \\
\text { - Credit risk: High }\end{array}$ \\
\hline
\end{tabular}


Table. Summary of Main Features of Selected Intervention Programs

\begin{tabular}{|c|c|c|c|c|}
\hline \multicolumn{5}{|c|}{ Table. Summary of Main Features of Selected Intervention Programs } \\
\hline $\begin{array}{c}\text { Facility } \\
\text { (Start Date) }\end{array}$ & Support Provided to & Intermediaries & Objectives & Main Features \\
\hline $\begin{array}{l}\text { AMLF (U.S.) } \\
\text { (September 2008) }\end{array}$ & $\begin{array}{l}\text { - } \mathrm{ABCP} \text { market } \\
\text { - Money market mutual } \\
\text { funds }\end{array}$ & Banks & $\begin{array}{l}\text { - } \text { Prevent fire sales in the ABCP } \\
\text { Market } \\
\text { - Support MMMFs } \\
\text { - Support the structured product } \\
\text { market } \\
\end{array}$ & $\begin{array}{l}\text { - } \text { Banks purchased ABCP from MMMFs } \\
\text { - Banks refinanced the paper at the Fed nonrecourse } \\
\text { - No capital charge for banks } \\
\text { - Minimum quality requirement } \\
\text { - No haircut. } \\
\text { - Credit risk: High }\end{array}$ \\
\hline $\begin{array}{l}\text { CPFF (U.S.) } \\
\text { (October 2008) }\end{array}$ & $\begin{array}{ll}\text { - } & \text { Commercial paper } \\
& \text { Market } \\
\text { - } & \text { Commercial paper } \\
& \text { Issuers }\end{array}$ & SPV (CPFF LLC) & $\begin{array}{l}\text { - Allow the primary CP market to } \\
\text { function } \\
\text { - Support CP Issuers } \\
\text { - Support banks } \\
\text { - Support the structured product } \\
\text { market }\end{array}$ & $\begin{array}{l}\text { - Purchase 90-day CP and ABCP from highly rated } \\
\text { U.S. issuers } \\
\text { - CP was held to maturity and nonrecourse } \\
\text { - Primary dealers acted as transaction agents } \\
\text { - Private sector firms supported asset management } \\
\text { and custody } \\
\text { - Minimum quality requirement } \\
\text { - Restrictions on amounts issued by facility } \\
\text { - } \text { Issuerticipants } \\
\text { - } \text { plus spreads } \\
\text { - Credit risk: Medium a signup fee and pay short rates } \\
\end{array}$ \\
\hline $\begin{array}{l}\text { TALF (U.S.) } \\
\text { (March 2009) }\end{array}$ & $\begin{array}{ll}\text { - Structured product } \\
\text { Market } \\
\text { - Structured product } \\
\text { Issuers }\end{array}$ & $\begin{array}{ll}\text { - } & \text { SPV (TALF LLC) } \\
\text { - } & \text { SP investors } \\
\text { - } & \text { Primary dealers }\end{array}$ & $\begin{array}{l}\text { - Support structured product issuers } \\
\text { - Restore functioning of the primary } \\
\text { SP market } \\
\text { - Support the secondary SP market } \\
\text { - Support consumers and businesses } \\
\text { who received funding from the SP } \\
\text { market }\end{array}$ & $\begin{array}{l}\text { - Provided nonrecourse term funding for SP, mainly } \\
\text { - } \text { FBS issued after } 1 / 1 / 2009 \\
\text { to-matity was multiyear, providing long-term, held- } \\
\text { the securities from the issuers } \\
\text { - Private sector firms assessed credit and provided } \\
\text { custody } \\
\text { - Minimum quality requirement } \\
\text { - TALF led to overall spread tightening in the SP } \\
\text { - } \text { markets due to signaling effect } \\
\text { - } \text { risk } \\
\text { - Haircuts were required; U.S. Treasury took } 2^{\text {nd }} \\
\text { loss position. } \\
\text { - Credit risk: Low-medium }\end{array}$ \\
\hline
\end{tabular}




\section{Appendix IV. A Summary of Lender-of-Last Resort Issues}

LOLR is a key component of a central bank's emergency response toolkit. ${ }^{1}$ LOLR involves the provision of liquidity - reserve money, foreign exchange (FX), or securities - at the central bank's discretion, to one or a small group of solvent and viable entities in order to meet sudden and temporary liquidity pressures that, if not addressed, could undermine financial stability. ${ }^{2}$ This function is performed under the central bank's financial stability mandate which is generally set out in the central bank's legislation; market participants therefore know that there is potentially a safety net available.

Central banks adopt different strategies in their LOLR frameworks. Although a "one-sizefits-all" approach may not be appropriate, given differing central bank mandates, collateral bases, exchange rate regimes, and regulatory frameworks, there are certain "one-size-fitsmost" principles as outlined below.

LOLR should be provided only to solvent and viable entities, assessed on an ongoing basis. However, differentiating liquidity from solvency problems may not be easy when timelines are tight; a level of judgment will be required, in consultation with the banking supervisor. Some central banks may choose to, or are restricted to, lend to systemically important institutions only. However, there is a strong argument in support of lending to all regulated solvent and viable banks, as even in normal times, contagion risk could mean that the failure of one viable but temporarily illiquid bank could have unintended consequences for the wider system.

In some instances, there may be a case for providing LOLR to certain nonbanks, but careful consideration needs to be given to the reasons for doing so and the way in which the support is structured. If the exceptional liquidity demand of nonbanks has arisen as a result of market inefficiencies or regulatory loopholes, policies should be put in place to limit or prevent these circumstances from arising again in the future. Support for nonbanks should not be seen as a pre-commitment, and should be restricted to certain regulated and supervised entities. Security dealers and systemically important central clearing counterparties may be an important subgroup. ${ }^{3}$

LOLR support should only be available to meet temporary liquidity needs while the counterparty should at all times demonstrate a credible prospect of repaying the operation on

\footnotetext{
${ }^{1}$ See Dobler and others (2016) for a discussion on the operational modalities relating to the provision of LOLR.

${ }^{2}$ This could arise when the illiquidity at one or more entities triggers a wider loss of confidence - on a retail, corporate, or wholesale basis - that spreads to otherwise sound institutions.

${ }^{3}$ Central clearing counterparties (CCPs) provide an example of where the support provided by central banks can extend beyond the strict definition of LOLR discussed so far. For example, following the default of some of its clearing members, central banks may choose to lend cash to CCPs in order to prevent it from distorting markets through the liquidation of a large securities portfolio, possibly at fire sale prices.
} 
or before maturity. Careful consideration should be given - particularly by public banks - as to why alternative sources of liquidity are not available. Importantly, LOLR operations should not be used for the concerned institution's own capital management exercises (such as debt buybacks).

LOLR support should at all times be adequately collateralized, with central banks having in place appropriate risk control and valuation methodologies. An entity requesting LOLR will normally have exhausted its high-quality assets and the central bank may have to accept any type of unencumbered asset, provided ownership can be legally transferred, it can be priced, and its risk can be adequately managed by the central bank.

An appropriate balance should be found in the pricing of central bank credit. The cost should be high enough to encourage banks to seek other forms of lending, but not too high so as to exacerbate liquidity strains and make survival of the institution (and repayment of LOLR) less likely. At a minimum, the rate charged should be above the cost of central bank monetary policy lending operations, including the standing credit facility rate.

Controls are needed to provide appropriate incentives and to minimize moral hazard and other risks. A key requirement is the ability for the central bank to impose-either directly or indirectly - supervisory intrusion and possible conditionality. Funding plans should be prepared early in the process — with supervisory input — as these provide a means of detecting problems early so that policy actions can be applied.

Government support should also be available, particularly when the central bank has concerns about the counterparty, collateral, scale of support, length, or exit strategy. This support is important to ensure that central bank autonomy can be preserved and its balance sheet protected.

Finally, central banks' communication with the market needs to be carefully considered. As financial crises are rarely the same, some flexibility should be retained in the framework that is published. Central banks should not overly restrict their ability to respond by precommitment, but could consider disclosing enough information on their framework so that the market can undertake appropriate contingency planning. In order to minimize concerns about stigma, consideration also needs to be given to the public information provided on usage. Some delay in disclosure would be necessary so that efforts to achieve the policy objective are not undermined. 


\section{References}

Acharya, V., A. Krishnamurthy, and E. Perotti, 2011. "A Consensus View on Liquidity Risk." Centre for Economic Policy Research, London. Available at http://voxeu.org/article/consensusview-liquidity-risk.

Altavilla, C., G. Carboni, and R. Motto, 2015, "Asset Purchase Programmes and Financial Markets: Lessons from the Euro Area.” Working Paper Series No. 1864, European Central Bank, Frankfurt, Germany.

Bagehot, W., 1873, Lombard Street: A Description of the Money Market, $4^{\text {th }}$ Edition. London: Henry S. King \& Co.

Bank of International Settlements (BIS), 2014. "Re-thinking the Lender-of-Last Resort," BIS Papers No. 79. BIS, Basel, Switzerland.

Bond, P. and Y. Leitner, 2015, "Market Run-Ups, Market Freezes, Inventories, and Leverage." Journal of Financial Economics 115 (1): 155-67.

Brunnermeier, Markus K., and Lasse Heje Pedersen, 2009. "Market liquidity and funding liquidity." Review of Financial Studies 22, no. 6: 2201-2238.

Buiter, W., and Sibert, A. 2007, "Central Banks as the Market-Maker of Last Resort: From Lender-of-Last-Resort to Market-Maker-of-Last-Resort.” blogs.ft.com

Canales-Kriljenko, J., R. Guimaraes, and C. Karacadag. 2003, "Official Intervention in the Foreign Exchange Market: Elements of Best Practice,” IMF Working Paper WP/03/152, International Monetary Fund, Washington, DC.

Committee on the Global Financial System (CGFS), 2014. "Market-Making and Proprietary Trading: Industry Trends, Drivers and Policy Implications." CGFS Papers No. 52, Bank for International Settlements, Basel, Switzerland.

_. 2016. "Fixed Income Market Liquidity," CGFS Papers No. 55, Bank for International Settlements, Basel, Switzerland.

Coval, Joshua, and Erik Stafford. 2007, "Asset Fire Sales (and Purchases) in Equity Markets," Journal of Financial Economics 86 (2): 479-512.

Davis, E.P. 1994. "Market Liquidity Risk," In The Competitiveness of Financial Institutions and Centres in Europe, edited by D. E. Fair and R. J. Raymond, 381-402. Berlin: Springer.

Diamond, D.W., and R.G. Rajan, 2011, "Fear of Fire Sales, Illiquidity Seeking, and Credit Freezes," The Quarterly Journal of Economics 126 (2): 557-91. 
Dobler, D., S. Gray, D. Murphy, and B. Radzewicz-Bak, “The Lender-of-Last Resort Function after the Global Financial Crisis," IMF Working Paper WP/16/10, International Monetary Fund, Washington, DC.

Dominguez, K. “The Market Microstructure of Central Bank Intervention," Journal of International Economics 59 (1): 25-45.

Dominguez, K., and J. Frankel. 1993, "Does Foreign Exchange Intervention Matter? The Portfolio Effect," The American Economic Review 83 (5): 1356-69.

Easley, D., M. M. López de Prado, and M. O'Hara, 2012, "Flow Toxicity and Liquidity in a High-Frequency World," Review of Financial Studies 25 (5): 1457-93.

Eckhold, K, and C. Hunt 2005, “The Reserve Bank’s New Foreign Exchange Intervention Policy," RBNZ Bulletin 68 (1): 12-22.

Enoch, Charles, 1998, "Transparency in Central Bank Operations in the Foreign Exchange Market," Paper on Policy Analysis and Assessment of the International Monetary Fund, PPAA/98/2, Washington, DC.

Evans, M., and R. Lyons, 2002. “Order Flow and Exchange Rate Dynamics.” Journal of Political Economy 110 (1): 170-80.

Henderson, D. and S. Sampson. 1983, "Intervention in Foreign Exchange Markets: A Summary of Ten Staff Studies," Federal Reserve Bulletin 69 (November): 830-36.

Hu, G.X., J. Pan, and J. Wang. 2013, "Noise as Information for Illiquidity," The Journal of Finance 68 (6): 2341-82.

International Monetary Fund (IMF), 2015, “Market Liquidity: Resilient or Fleeting?” In Global Financial Stability Report, October 2015, chapter 2, Washington, DC: International Monetary Fund.

Ishii, S., J. Canales-Kriljenko, R. Guimarles, and C. Karacadag. 2006. “Official Foreign Exchange Intervention.” IMF Occasional Paper 249, International Monetary Fund, Washington, DC.

Jotikasthira, Chotibhak, Christian Lundblad, and Tarun Ramadorai. 2012, "Asset Fire Sales and Purchases and the International Transmission of Funding Shocks," The Journal of Finance 67 (6): 2015-50.

Klemperer, P. 1999, "Auction Theory: A Guide to the Literature," Journal of Economic Surveys 13 (3): 227-86.

Malherbe, F. 2014, “Self-Fulfilling Liquidity Dry-Ups,” The Journal of Finance 69 (2): 947-70. 
Li, Zhao, and Kebin Ma, 2016. "A theory of endogenous asset fire sales, bank runs, and contagion," mimeo.

Marx, A., and M. Connolly, 2015, "Fidelity's View on Bond-Market Liquidity," Leadership Series, October, Pyramis Global Advisors, Smithfield, Rhode Island.

Moreno R. "Motives for Intervention," 2005. In Foreign Exchange Market Intervention in Emerging Markets: Motives, Techniques, and Implications, BIS Papers No. 24 (May), 4-18. Basel, Switzerland: Bank for International Settlements.

Pasquariello, Paolo, 2014, "Financial Market Dislocations," Review of Financial Studies 27 (6): 1868-1914.

Pulvino, Todd C. 1998, "Do Asset Fire Sales Exist? An Empirical Investigation of Commercial Aircraft Transactions," The Journal of Finance 53 (3): 939-78.

Rogoff, K. 1984, "On the Effects of Sterilized Intervention: An Analysis of Weekly Data." Journal of Monetary Economics 14 (September): 133-50.

Schinasi, G. 2006, Safeguarding Financial Stability: Theory and Practice. Washington, DC: International Monetary Fund.

Shleifer, Andrei, and Robert Vishny, 2011. "Fire Sales in Finance and Macroeconomics," The Journal of Economic Perspectives 25 (1): 29-48.

Stella, P. 2002, “Central Bank Financial Strength, Transparency, and Policy Credibility,” IMF Working Paper WP/02/137, International Monetary Fund, Washington, DC. 